\title{
Micro-aerobic bacterial methane oxidation in the chemocline and anoxic water column of deep south-Alpine Lake Lugano (Switzerland)
}

\author{
Jan Blees, ${ }^{1,}{ }^{*}$, a Helge Niemann, ${ }^{1}$ Christine B. Wenk, ${ }^{1}$ Jakob Zopfi, ${ }^{1}$ Carsten J. Schubert, ${ }^{2}$ \\ Mathias K. Kirf, ${ }^{2}$ Mauro L. Veronesi, ${ }^{3}$ Carmen Hitz, ${ }^{1}$ and Moritz F. Lehmann ${ }^{1}$ \\ ${ }^{1}$ Department of Environmental Sciences, University of Basel, Basel, Switzerland \\ ${ }^{2}$ Department of Surface Waters-Research and Management, Swiss Federal Institute of Aquatic Science and Technology (EAWAG), \\ Kastanienbaum, Switzerland \\ ${ }^{3}$ Institute of Earth Sciences, University of Applied Sciences of Southern Switzerland, Campus Trevano, Canobbio-Lugano, Switzerland
}

\begin{abstract}
We measured seasonal variations in the vertical distribution of methane concentration, methane oxidation rates, and lipid biomarkers in the northern basin of Lake Lugano. Methane consumption below the oxic-anoxic interface co-occurred with concentration maxima of ${ }^{13} \mathrm{C}$-depleted $\mathrm{C}_{16}$ fatty acid biomarkers (with $\delta^{13} \mathrm{C}$ values as low as $-70 \%$ ) in the anoxic water column, as well as characteristic $\delta^{13} \mathrm{C}_{\mathrm{CH}_{4}}$ profiles. We argue that the conspicuous methane concentration gradients are primarily driven by (micro-)aerobic methane oxidation (MOx) below the chemocline. We measured a strong MOx potential throughout the anoxic water column, while MOx rates at in situ $\mathrm{O}_{2}$ concentration $>10 \mathrm{nmol} \mathrm{L}-1$ were undetectable. Similarly, we found MOx-related biomarkers and gene sequences encoding the particulate methane monooxygenase in the anoxic, but not the oxic, water. The mechanism of (episodic) oxygen supply sustaining the MOx community in anoxic waters is still uncertain. Our results indicate that a bacterial methanotrophic community is responsible for the methane consumption in Lake Lugano, without detectable contribution from archaeal methanotrophs. Bacterial populations that accumulated both at the suboxic-anoxic interface and in the deeper anoxic hypolimnion, where maximum potential MOx rates were observed throughout the year $\left(1.5-2.5 \mu \mathrm{mol} \mathrm{L}^{-1} \mathrm{~d}^{-1}\right)$ were mainly related to Methylobacter sp. Close relatives are found in lacustrine environments throughout the world, and their potential to thrive under micro- and anoxic conditions in Lake Lugano may imply that micro-aerobic methane oxidation is important in methane cycling and competition for methane and oxygen in stratified lakes worldwide.
\end{abstract}

The concentration of atmospheric methane $\left(\mathrm{CH}_{4}\right)$ has increased by 2.4 times since the pre-industrial era (IPCC 2007). On a per-mol basis and on a $100 \mathrm{yr}$ time horizon, $\mathrm{CH}_{4}$ is a 25 times more efficient greenhouse gas than is $\mathrm{CO}_{2}$, contributing $\sim 18 \%$ to the total radiative forcing of long-lived greenhouse gases (IPCC 2007). Consequently, an in-depth knowledge of the $\mathrm{CH}_{4}$ cycle is paramount to the assessment of present-day and future climate change. Natural $\mathrm{CH}_{4}$ sources to the atmosphere are very important, constituting about $30 \%$ of total $\mathrm{CH}_{4}$ emissions (Chen and Prinn 2006). In particular, wetlands and lakes are major $\mathrm{CH}_{4}$ emitters, of which the latter contribute up to $16 \%$ of total natural sources (Bastviken et al. 2004). $\mathrm{CH}_{4}$ is produced by specialized Archaea (methanogens) in anoxic environments, such as lacustrine sediments, where it typically accumulates to high concentrations. In well-mixed lakes, a significant fraction of $\mathrm{CH}_{4}$ is subsequently consumed with oxygen at the sediment-water interface (Bastviken et al. 2002). During stratified conditions, however, the flux of oxygen $\left(\mathrm{O}_{2}\right)$ across density gradients in the water column is hindered, so that aerobic processes lead to $\mathrm{O}_{2}$ depletion in bottom waters (Diaz and Rosenberg 2008; Zaikova et al. 2010). Consequently, $\mathrm{CH}_{4}$ is liberated

\footnotetext{
*Corresponding author: jan.blees@unibas.ch

a Present address: Laboratory of Atmospheric Chemistry, Paul Scherrer Institute, Switzerland
}

into the water column, where it may accumulate. In lakes, density stratification is typically interrupted by one or two mixing events a year (mono- or dimictic regimes, respectively). Alternatively, lakes can exhibit permanent stratification (meromixis) with a stable chemocline. Particularly narrow and deep lakes, with a low surface to volume ratio, or systems experiencing little physical disturbance (e.g., wind stress) are prone to developing meromixis.

In contrast to the marine realm, where anaerobic oxidation of $\mathrm{CH}_{4}(\mathrm{AOM})$ coupled to sulfate $\left(\mathrm{SO}_{4}^{2-}\right)$ reduction (S-AOM) is an efficient sink for $\mathrm{CH}_{4}$ (Knittel and Boetius 2009), the S-AOM CH 4 filter does not work in sulfate-depleted freshwater reservoirs, and $\mathrm{CH}_{4}$ was long thought to be oxidized exclusively by aerobic methane oxidizing bacteria (MOB; Hanson and Hanson 1996; Trotsenko and Murrell 2008). Indeed, maximum MOB abundances and highest rates of aerobic methanotrophy (MOx) are found at oxic-anoxic interfaces in sediments and water columns (Rudd et al. 1976). Yet biogeochemical indications of $\mathrm{CH}_{4}$ consumption in anoxic freshwater environments exist (Panganiban et al. 1979; Crowe et al. 2010; Schubert et al. 2010). To some degree this could be attributed to S-AOM operating at relatively low $\mathrm{SO}_{4}^{2-}$ concentrations. However, the recent discovery of anaerobic $\mathrm{CH}_{4}$ oxidizing bacteria utilizing molecular oxygen from the conversion of $\mathrm{NO}_{2}^{-}$to $\mathrm{N}_{2}$ and $\mathrm{O}_{2}$ (Ettwig et al. 2009, 2010) and, as of yet-unidentified, microbial communities utilizing iron $(\mathrm{Fe})$ or manganese $(\mathrm{Mn})$ as an electron acceptor for 
$\mathrm{CH}_{4}$ oxidation (Beal et al. 2009; Crowe et al. 2010; Sivan et al. 2011) raise the question of whether $\mathrm{CH}_{4}$ stored in these waterbodies may be consumed through processes other than S-AOM and MOx. Finally, if MOB in freshwater bodies rely on $\mathrm{O}_{2}$ as the oxidant, it remains uncertain to what extent aerobic MOB are able to survive, and possibly thrive, under micro-oxic or anoxic conditions.

Possible differences between the isotope effects of (micro-) aerobic and anaerobic $\mathrm{CH}_{4}$ oxidation may result in distinct shifts in the isotopic composition of residual $\mathrm{CH}_{4}$, which can in turn be used diagnostically to distinguish the methanotrophic modes at work. While the $\mathrm{C}$-isotopic fractionation of MOx has been the subject of intensive field and laboratory studies (Whiticar and Faber 1986; Jahnke et al. 1999), the isotope effects of $\mathrm{AOM}$, or the isotopic expression of MOx under micro-oxic conditions or severe substrate limitation, are not well constrained.

The northern basin of Lake Lugano provides a natural laboratory in which to study $\mathrm{CH}_{4}$ oxidation under different redox regimes in a freshwater environment, as it is characterized by meromixis and features a $\mathrm{CH}_{4}$-rich hypolimnion (Barbieri and Mosello 1992; Barbieri and Simona 2001). Previous work in the northern basin of Lake Lugano (Liu et al. 1996) has shown deep hypolimnetic $\mathrm{CH}_{4}$ concentration profiles and enrichment of ${ }^{13} \mathrm{C}$ in the residual $\mathrm{CH}_{4}$ pool, suggesting a $\mathrm{CH}_{4}$ sink well within the anoxic part of the water column. In this study, we question whether this apparent $\mathrm{CH}_{4}$ sink represents $\mathrm{AOM}$, or rather micro-aerobic $\mathrm{CH}_{4}$ oxidation at sub-micromolar $\mathrm{O}_{2}$ concentrations that are undetectable by traditional $\mathrm{O}_{2}$ concentration measurement techniques. We applied an interdisciplinary approach that combines lipid biomarker, stable, and radioactive isotope methods, and we made use of a newly developed $\mathrm{O}_{2}$ sensing system that allows determination of sub-micromolar $\mathrm{O}_{2}$ concentration. The aims of this study were (1) to quantify rates of $\mathrm{CH}_{4}$ oxidation in the epi-, meta-, and hypolimnion of the lake's northern basin, and thus to evaluate the importance of potential modes of $\mathrm{CH}_{4}$ oxidation; (2) to identify the methanotrophic community; and (3) to study the effect of micro-aerobic $\mathrm{CH}_{4}$ consumption on the $\mathrm{C}$-isotopic composition of the hypolimnetic $\mathrm{CH}_{4}$ and organic carbon pools. We show that despite seemingly clear indications of AOM in the geochemical profiles, micro-aerobic $\mathrm{CH}_{4}$ oxidation is the prime mode of $\mathrm{CH}_{4}$ oxidation in the northern basin of Lake Lugano.

\section{Methods}

Study site-Lake Lugano is a south-alpine lake located on the Swiss-Italian border, at an elevation of $271 \mathrm{~m}$ above mean sea level. It consists of two basins separated by a natural dam. The northern basin is a former glacial valley with a fjord-like bathymetry surrounded by steep mountains. The maximum water depth is $288 \mathrm{~m}$. The water input by tributaries is relatively small, resulting in a long mean hydrological residence time of $\sim 12 \mathrm{yr}$ (Aeschbach-Hertig et al. 2007). A small surface-to-volume ratio, low average wind speeds, and ongoing eutrophication have led to the development of meromixis, with a permanent chemocline in intermediate water depths and an anoxic hypolimnion since the early 1960s (Barbieri and Mosello 1992; Aeschbach-Hertig et al. 2007). The sole exception to this was a brief period of deep water ventilation in 2005 and 2006 (Holzner et al. 2009), after which the chemocline reestablished at $135 \mathrm{~m}$ water depth.

Sampling - Sampling campaigns were conducted during different seasons in April 2008; March, June, August, and October 2009; January and August 2010; September and October 2011; and January and May 2012 (Table 1). All sampling casts were performed in the middle of the lake's northern basin $\left(46.01^{\circ} \mathrm{N}, 9.02^{\circ} \mathrm{E}\right)$. Temperature, conductivity, $\mathrm{O}_{2}$ concentration, $\mathrm{pH}$, and turbidity were measured with a conductivity, temperature, and depth (CTD) device (Idronaut Ocean Seven 316 Plus, Idronaut). $\mathrm{O}_{2}$ concentration measurements of the CTD's $\mathrm{O}_{2}$ sensor were calibrated against Winkler titration measurements, and the detection limit was deter-

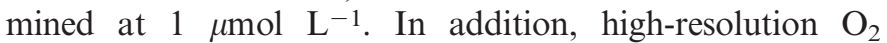
concentration measurements with nanomolar sensitivity were performed across the oxic-anoxic interface using highly amplified amperometric sensors and oxygen optodes (Kirf et al. 2013). The in situ detection limit $(2 \times$ standard deviation) of the amperometric oxygen microsensor was $4.5 \pm$ $0.7 \mathrm{nmol} \mathrm{L}-1$. Water samples were collected in 5 or 10 liter Niskin bottles, and subsamples were taken directly from the Niskin bottle through silicon tubing. A sediment core was collected with a gravity corer in April 2008. Sediments for $\mathrm{CH}_{4}$ analyses were extracted from the core liner through predrilled holes using cutoff syringes at a $5 \mathrm{~cm}$ resolution.

Hydrochemical analyses - Samples for Fe(II) and total sulfide were fixed on board, and concentrations were determined photometrically. Dissolved Fe(II) was quantified using the 'bipyridine method' (Hill 1930). Additional unfiltered water samples were collected for determination of total Fe through reduction of oxidized Fe-species with hydroxylamine hydrochloride prior to the analysis of the evolved Fe(II) with the bipyridine method. Fe(III) concentration was then calculated as the difference between $\mathrm{Fe}(\mathrm{II})$ and total $\mathrm{Fe}$. Samples for total sulfide $(2 \mathrm{~mL})$ were fixed in aqueous zinc acetate solution (1\% final concentration) and subsequently analyzed using the ethylene blue method (Rees et al. 1971). $\mathrm{SO}_{4}^{2-}$ samples were measured by ion chromatography.

Dissolved methane-Water column samples for the determination of $\mathrm{CH}_{4}$ concentration and its stable $\mathrm{C}$ isotopic composition were collected in $500 \mathrm{~mL}$ glass bottles, which were immediately sealed with thick butyl rubber stoppers. Subsequently, a $10 \mathrm{~mL}$ headspace was introduced, and $10 \mathrm{~mL}$ of aqueous $\mathrm{NaOH}$ solution $(50 \%$, w: v) was added in exchange with sample in order to stop microbial activity and to expel dissolved $\mathrm{CH}_{4}$ into the headspace. For concentration and $\delta^{13} \mathrm{C}-\mathrm{CH}_{4}$ measurements in the sediment, samples were amended immediately with $5 \mathrm{~mL} \mathrm{NaOH}(2.5 \%$, w:v) in $20 \mathrm{~mL}$ butyl rubbersealed glass vials. $\mathrm{CH}_{4}$ concentrations were determined with a gas chromatograph (GC, Agilent 6890N) equipped with a $30 \mathrm{~m}$ Supelco Carboxen 1010 porous layer open tubular (PLOT) column ( $0.53 \mathrm{~mm}$ inner diameter) and a flame ionization detector (FID). ${ }^{13} \mathrm{C}:{ }^{12} \mathrm{C}$ ratios were 
Table 1. Overview of measured parameters and incubations.

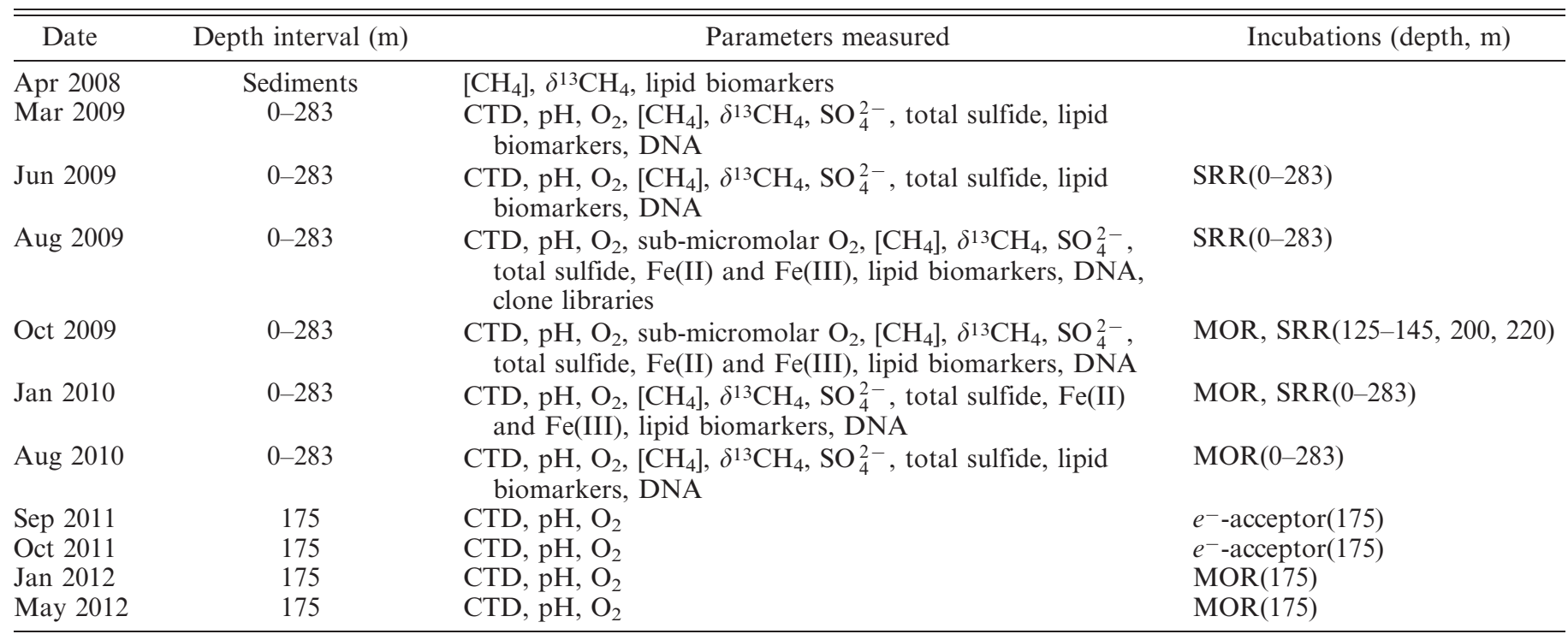

analyzed with an isotope ratio mass spectrometer (IRMS, Isoprime) subsequent to gas chromatography (Isoprime TraceGas) and pre-concentration with a cryo-trap. Corrections were made for linearity effects and instrument drift. Stable $\mathrm{C}$ isotope ratios are reported in the conventional $\delta$ notation (in \%o) relative to Vienna Pee Dee Belemnite. $\mathrm{CH}_{4}$ $\delta^{13} \mathrm{C}$-values reported here have an analytical error of $\pm 1 \%$.

Apparent kinetic isotope enrichment factors were calculated using a closed-system approach (Mariotti et al. 1981), as follows:

$$
\varepsilon_{\text {closed }}=\frac{10^{3} \ln \frac{10^{-3} \delta_{s}+1}{10^{-3} \delta_{s, 0}+1}}{\ln f}
$$

and according to an open-system approach (Sigman et al. 2003), thus:

$$
\varepsilon_{\text {open }}=\frac{\delta_{s}-\delta_{s, 0}}{1-f}
$$

where $\varepsilon$ is the enrichment factor (in \%o) between product and substrate, $\delta_{\mathrm{s}}$ and $\delta_{\mathrm{s}, 0}$ are the $\delta^{13} \mathrm{C}$ values of $\mathrm{CH}_{4}$ at a considered depth and the $\delta^{13} \mathrm{C}$ of the source $\mathrm{CH}_{4}$, respectively, and $f$ is the fraction of $\mathrm{CH}_{4}$ remaining.

Methane oxidation rates-Triplicate samples for methane oxidation rate (MOR) measurements were collected in $25 \mathrm{~mL}$ crimp-top serum vials. Immediately after sampling the vials were capped bubble-free with gray bromo-butyl stoppers (Helvoet Pharma, Belgium). Samples were stored cooled $\left(4^{\circ} \mathrm{C}\right)$ for transport to the laboratory. Radiotracer was added about $24 \mathrm{~h}$ after sampling by injecting a $10 \mu \mathrm{L}$ bubble of ${ }^{14} \mathrm{CH}_{4}: \mathrm{N}_{2}$ gas $(\sim 10 \mathrm{kBq})$. The bubble dissolved within an hour (Mau et al. 2013). Samples were incubated at in situ temperature. Time series of up to $4.5 \mathrm{~d}$ (time points at $10,30,50,72$, and $104 \mathrm{~h}$ after incubation start) were performed on two depths in each profile in order to determine linearity of $\mathrm{CH}_{4}$ turnover, and single end-point measurements were used for the remaining depths. All samples were incubated in triplicate. Killed controls were analyzed for each profile. Similar to $\mathrm{CH}_{4}$ concentration measurements, the incubation was terminated by fixing the samples with $0.5 \mathrm{~mL}$ of aqueous $\mathrm{NaOH}$ solution and introducing $5 \mathrm{~mL}$ headspace. $\mathrm{CH}_{4}$ concentration in the headspace was quantified by GC-FID. Separation of remaining ${ }^{14} \mathrm{CH}_{4}$ in the headspace and the produced ${ }^{14} \mathrm{CO}_{3}^{2-}$ in the aqueous phase of the fixed sample was achieved by flushing the headspace with a continuous stream of air $\left(30 \mathrm{~mL} \mathrm{~min} \mathrm{~m}^{-1}\right.$ for $30 \mathrm{~min})$. The stripped ${ }^{14} \mathrm{CH}_{4}$ was further transported through an oxidation reactor (quartz tubing filled with $\mathrm{CuO}$ at $850^{\circ} \mathrm{C}$ ), where it was transformed into ${ }^{14} \mathrm{CO}_{2}$, which was then trapped in a methoxyethanol:phenylethylamine $(7: 1 \mathrm{v}: \mathrm{v}$, $8 \mathrm{~mL}$ ) solution (Treude et al. 2003). The alkaline water phase was subsequently acidified to $\mathrm{pH}<1$ in order to shift the carbonate equilibrium toward $\mathrm{CO}_{2}$. The liberated ${ }^{14} \mathrm{CO}_{2}$ was then purged and trapped as described above (Mau et al. 2013). ${ }^{14} \mathrm{C}$ activity was analyzed by liquid scintillation counting. Recovery was $>95 \%$, as determined with synthetic $\mathrm{H}^{14} \mathrm{CO}_{3}^{-}$. Finally, any remaining ${ }^{14} \mathrm{C}$ activity in the (acidified) water was determined in an $8 \mathrm{~mL}$ aliquot by liquid scintillation counting.

The first-order rate constant $(k)$ was calculated from the activity of the three carbon pools as follows:

$$
k=\frac{A_{\mathrm{CO}_{2}}+A_{\mathrm{R}}}{A_{\mathrm{CH}_{4}}+A_{\mathrm{CO}_{2}}+A_{\mathrm{R}}} \times \mathrm{d}^{-1}
$$

where $A_{\mathrm{CH}_{4}}, A_{\mathrm{CO}_{2}}$, and $A_{\mathrm{R}}$ represent the radioactivity of $\mathrm{CH}_{4}, \mathrm{CO}_{2}$, and the remaining radioactivity (which includes biomass and metabolic intermediates), respectively. Potential $\mathrm{CH}_{4}$ oxidation rates (MOR) were then calculated assuming first-order kinetics:

$$
\operatorname{MOR}=k \times\left[\mathrm{CH}_{4}\right] \text {, in } \mu \mathrm{mol} \mathrm{L}-1 \mathrm{~d}^{-1}
$$

where $\left[\mathrm{CH}_{4}\right]$ is the $\mathrm{CH}_{4}$ concentration at the start of incubation, calculated from the concentration at the end of the incubation period and from the turnover fraction. Even in originally anoxic samples, minor $\mathrm{O}_{2}$ contamination took 
place during tracer injection, and diffusion of trace amounts of $\mathrm{O}_{2}$ from the butyl elastomer could not be prevented, so that incubations evidentially took place under micro-oxic or suboxic conditions. Therefore, and since our analyses revealed the presence of aerobic methanotrophic communities, but not of microbes known to be involved in anaerobic modes of methane oxidation (see discussion below), reported rates should consequently be considered as potential aerobic MOR.

Sulfate reduction rates - Samples for sulfate reduction rate (SRR) measurements were collected as described for MOR incubations. Incubations were amended with $10 \mu \mathrm{L}$ aqueous ${ }^{35} \mathrm{SO}_{4}^{2-}$ solution $(100 \mathrm{kBq})$ and incubated for up to $24 \mathrm{~d}$ at in situ temperature. All samples were incubated in triplicate. Incubations were terminated, and produced sulfide was fixed by addition of $15 \mathrm{~mL}$ aqueous zinc acetate solution $(20 \%, \mathrm{w}: \mathrm{v})$ in $50 \mathrm{~mL}$ centrifuge tubes. Artificial sediment (kaolinite) was then added to facilitate precipitation of zinc sulfide, and samples were stored at $-20^{\circ} \mathrm{C}$ until further analysis. Sulfate reduction rates were determined via single-step cold chromium distillation and liquid scintillation counting of reduced ${ }^{35} \mathrm{~S}$ compounds and remaining ${ }^{35} \mathrm{SO}_{4}^{2-}$ tracer, according to the method of Kallmeyer et al. (2004). Rates were calculated analogously to the approach described for $\mathrm{CH}_{4}$ oxidation rates (Eqs. 3 and 4).

Flux calculations in the water column-Vertical turbulent-diffusive fluxes of solutes in the water column were calculated as

$$
F_{z}=-K_{z} \frac{d C}{d z}
$$

where $F_{z}$ is the vertical flux of the solute, $K_{z}$ is the vertical eddy diffusivity, and $d C / d z$ is the solute concentration gradient over depth interval $z$. For August 2010, $K_{z}$ was estimated for the depth interval between 135 and $145 \mathrm{~m}$ water depth by dividing the $\mathrm{CH}_{4}$ flux through the horizontal section (from methane oxidation rate measurements, under the simplified assumption of a $1 \mathrm{~m}$ thick reaction zone) by the $\mathrm{CH}_{4}$ concentration gradient (Zopfi et al. 2001). The estimated value of $3.3 \times 10^{-5} \mathrm{~m}^{2} \mathrm{~s}^{-1}$ agrees well with previously reported values for the northern basin of Lake Lugano (Wüest et al. 1992). $K_{z}$ varies with depth. It depends on the buoyancy frequency, and can be expressed as follows (Gargett 1984):

$$
K_{z}=a_{0} \times\left(\frac{-g}{\rho_{z}} \times \frac{d \rho}{d z}\right)^{-0.5}
$$

where $g$ is the standard gravity, $\rho_{z}$ is the density at depth $z$ $(145 \mathrm{~m})$, and $d \rho / d z$ is the density gradient between 135 and $145 \mathrm{~m}$ water depth. We then solved Eq. 6 for $a_{0}$ and obtained an $a_{0}$ of $3.2 \times 10^{-8} \mathrm{~m}^{2} \mathrm{~s}^{-2}$, which is characteristic for restricted basins (Gargett 1984). The factor $a_{0}$ is a system-specific constant, which we then used to calculate $K_{z}$ at other depths, based on density profiles alone, allowing calculation of the turbulent-diffusive flux of $\mathrm{CH}_{4}$ and $\mathrm{O}_{2}$ toward the chemocline throughout the year.
Particulate organic carbon-Particulate organic carbon (POC) was analyzed from lake water samples $(\sim 5$ liters $)$ filtered through pre-combusted glass-fiber filters (GF-F, Whatman) by applying a gentle vacuum $\left(\sim 0.5 \times 10^{5} \mathrm{~Pa}\right)$. Filters were then wrapped in aluminum foil and stored frozen $\left(-20^{\circ} \mathrm{C}\right)$. Bulk stable carbon isotopic composition of POC was determined on filter pieces of $1 \mathrm{~cm}^{2}$, which had been decarbonated in a dessicator with fumes of concentrated $\mathrm{HCl}$. The remaining organic carbon was combusted to $\mathrm{CO}_{2}$ in a Flash EA elemental analyzer (Flash EA 1112, Thermo Finnigan), and the $\delta^{13} \mathrm{C}$ of the $\mathrm{CO}_{2}$ was determined online on a Delta V Advantage IRMS (Thermo Finnigan). POC $\delta^{13} \mathrm{C}$ values reported here have an analytical error of $<0.2 \%$.

Biomarker analyses - Extraction and derivatization: Lipid biomarkers were extracted according to the method of Elvert et al. (2003). Briefly, a total lipid extract (TLE) was obtained by ultrasonication of filter samples in four steps, with solvents of decreasing polarity: (1) dichloromethane (DCM) : methanol (MeOH) $1: 2$; (2) DCM : $\mathrm{MeOH} 2: 1$; and $(3,4)$ DCM. Further separation into polar lipid-derived fatty acid (FA), hydrocarbon, ketone, and alcohol fractions, as well as derivatization of FAs and alcohols into FA methyl esters and trimethylsilyl ethers, respectively, was carried out according to the methods outlined in previous works (Elvert et al. 2003; Niemann et al. 2005). In short, the TLE was saponified with methanolic $\mathrm{KOH}$. The neutral fraction, comprising hydrocarbons, ketones, and alcohols, was then extracted from the saponified TLE with hexane. The remaining TLE containing the FAs was then acidified, and the protonated FAs were extracted with hexane and methylated with methanolic $\mathrm{BF}_{3}$. Double bond positions were determined through analysis of their dimethyldisulfide adducts (Nichols et al. 1986; Moss and Lambert-Fair 1989). Hydrocarbons, ketones, and alcohols were separated over a $\mathrm{SiOH}$ glass cartridge. Alcohols were subsequently methylated with bis(trimethylsilyl)trifluoracetamide.

Quantification, identification, and stable carbon isotope composition: Individual compounds were separated by GC (Trace GC Ultra, Thermo Scientific equipped with a split-splitless injector operated in splitless mode at $300^{\circ} \mathrm{C}$ ) over a capillary column $\left(\mathrm{Rxi}^{\circledR}{ }^{\circledR}-5 \mathrm{~ms}, 60 \mathrm{~m} \times 0.25 \mathrm{~mm}\right.$ inner diameter $\times 0.25 \mu \mathrm{m}$ film thickness) with a constant

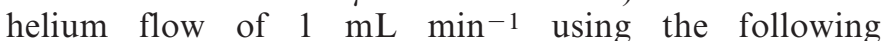
temperature program: initial oven temperature was $50^{\circ} \mathrm{C}$, held for $2 \mathrm{~min}$ and then increased to $140^{\circ} \mathrm{C}$ at a rate of $10^{\circ} \mathrm{C} \mathrm{min}-1$, then to $300^{\circ} \mathrm{C}$ with $4^{\circ} \mathrm{C} \mathrm{min}-1$, and finally held at $300^{\circ} \mathrm{C}$ for $63 \mathrm{~min}$. The abundance of individual compounds was quantified by FID. Concentrations were calculated against an internal standard and corrected for introduction of carbon atoms. Identification of single compounds was achieved by GC-mass spectrometry with electron ionization (Thermo Scientific DSQ II Dual Stage Quadrupole). Acquired mass spectra were identified through comparison with known standards and published data. Compound-specific stable carbon isotope ratios were determined using a GC-IRMS (Delta V Advantage, Thermo Scientific). As with concentrations, $\delta^{13} \mathrm{C}$ values were corrected for introduced carbon atoms. 
Reproducibility was monitored by repeated injections and monitoring of internal standards. Reported $\delta^{13} \mathrm{C}$ values have an analytical error of $\pm 1 \%$.

$D N A$ extraction, polymerase chain reaction, and cloningParticulate matter for phylogenetic analyses was collected by filtering $500 \mathrm{~mL}$ of lake water through $0.2 \mu \mathrm{m}$ polycarbonate membrane filters (Cyclopore, Whatman). Filters were frozen immediately and stored at $-70^{\circ} \mathrm{C}$ until extraction of deoxyribonucleic acid (DNA) using a FastDNA ${ }^{\circledR}$ SPIN Kit for Soil (MP Biomedicals). In order to analyze the phylogeny of bacterial methanotrophs, the gene coding for particulate methane mono-oxygenase (pMMO) was targeted. Polymerase chain reaction (PCR) of the alpha subunit of the pMMO gene (pmoA) was performed using primers A189f (5'GGNGACTGGGACTTCTGG3'; Holmes et al. 1995) and mb661r (5'CCGGMGCAACGTCYTTACC3'; Costello and Lidstrom 1999). Reactions were carried out in $50 \mu \mathrm{L}$ (total volume) mixtures following a protocol adapted from Shrestha et al. (2008).

Reaction mixtures contained $5 \mu \mathrm{L}$ of $1: 10$ diluted template DNA, $10 \mu \mathrm{L} 5 \times$ Phusion ${ }^{\circledR}$ HF buffer (Finnzymes, Thermo Fisher Scientific), $200 \mu \mathrm{mol} \mathrm{L}{ }^{-1}$ of each dNTP, $0.2 \mu \mathrm{mol} \mathrm{L}^{-1}$ of each primer, $3 \%$ dimethyl sulfoxide (final concentration), and 1 unit of Phusion ${ }^{\circledR}$ High-Fidelity DNA polymerase (Finnzymes, Thermo Fisher Scientific). PCR conditions were as follows: initial denaturation at $98^{\circ} \mathrm{C}$ for $2 \mathrm{~min}$, then 30 cycles of $30 \mathrm{~s}$ denaturation at $98^{\circ} \mathrm{C}, 30 \mathrm{~s}$ primer annealing at $57^{\circ} \mathrm{C}$, and $30 \mathrm{~s}$ elongation at $72^{\circ} \mathrm{C}$, followed by a final elongation step of $10 \mathrm{~min}$ at $72^{\circ} \mathrm{C}$. PCR products of four separate $50 \mu \mathrm{L}$ reactions were combined and concentrated to $25 \mu \mathrm{L}$ using a Wizard SV PCR cleanup kit (Promega). Amplicon length was checked on a 1.2\% agarose gel. Clone libraries of samples from 135 and $170 \mathrm{~m}$ water depth (August 2009) were constructed using the Zero Blunt ${ }^{\circledR}$ TOPO $^{\circledR}$ PCR Cloning Kit (Invitrogen). Restriction digestion analysis using MspI (Costello and Lidstrom 1999; Bussmann et al. 2006) was performed in order to assess the number of phylotypes. The obtained DNA sequences, as well as the most closely related representatives retrieved from the National Center for Biotechnology Information database, were translated into their amino acid sequences and aligned by the Muscle implementation in MEGA5 (Tamura et al. 2011). Phylogenetic trees were constructed in MEGA5 using the neighbor-joining algorithm, and evolutionary distances were calculated using the Poisson correction method. Sequences reported in this study were deposited in the European Molecular Biology Laboratory Bank under the accession numbers HF674401-9.

\section{Results}

Physical parameters, oxygen, and nutrients-A strong thermocline developed at $20 \mathrm{~m}$ water depth in the northern basin of Lake Lugano in spring. Density stratification at the thermocline prevented exchange of water from the epilimnion and the hypolimnion. Below $\sim 50 \mathrm{~m}$ water depth, the temperature remained stable at $5.7^{\circ} \mathrm{C}$ throughout the year. In late winter, cooling of surface waters destabilized the thermocline, leading to ventilation of the metalimnion (20-50 $\mathrm{m}$ water depth). The waterbody below $50 \mathrm{~m}$ depth, however, remained stratified throughout the whole duration of our study. The lack of water exchange deeper than $50 \mathrm{~m}$ is evidenced by decreasing $\mathrm{O}_{2}$ concentration below this depth (Fig. 1a). During the sampling campaigns between March 2009 and May 2012, the oxic-anoxic interface, as determined with the CTD oxygen sensor $\left(\left[\mathrm{O}_{2}\right]\right.$ $<1 \mu \mathrm{mol} \mathrm{L}^{-1}$, here defined as the CTD- $\mathrm{O}_{2}$-zero), was stable at 125 to $130 \mathrm{~m}$ water depth (Fig. 1a). $\mathrm{O}_{2}$ concentration data obtained with the combined amperometric $\mathrm{O}_{2}$ sensor and $\mathrm{O}_{2}$ optode showed that the oxic-anoxic interface, defined as $\left[\mathrm{O}_{2}\right]$ $<10 \mathrm{nmol} \mathrm{L}^{-1}$, was located between 125.6 and $128.2 \mathrm{~m}$ water depth (Fig. 1a), i.e., within the range reported by the CTD$\mathrm{O}_{2}$-sensor. The sub-micromolar zone, where $\left[\mathrm{O}_{2}\right]$ ranged between 1000 and $10 \mathrm{nmol} \mathrm{L}^{-1}$, had a thickness of $1.55 \pm$ $0.36 \mathrm{~m}$ (three casts). This indicates that in the northern basin of Lake Lugano the CTD- $\mathrm{O}_{2}$-zero approximates the true $\mathrm{O}_{2^{-}}$ zero. In the oxic hypolimnion above the chemocline, $\mathrm{NO}_{3}^{-}$ was present and decreased linearly toward the chemocline (Wenk et al. 2013). No $\mathrm{NO}_{3}^{-}$was detected below $150 \mathrm{~m}$ water depth. $\mathrm{NH}_{4}^{+}$was absent in the oxygenated hypolimnion, but its concentration increased below the redox transition zone to $>20 \mu \mathrm{mol} \mathrm{L} \mathrm{L}^{-1}$ in the bottom water. There, Fe(II) accumulated to $8 \mu \mathrm{mol} \mathrm{L}^{-1}$ (Fig. 2a). Fe(III) concentrations were consistently below $0.5 \mu \mathrm{mol} \mathrm{L}-1$ throughout the water column (and undetectable between 135 and $80 \mathrm{~m}$ depth), with the exception of the upper $20 \mathrm{~m}$ of the water column, where concentrations of $\sim 1 \mu \mathrm{mol} \mathrm{L}{ }^{-1}$ were observed (Fig. 2b). Sulfide was detected at depths $>140 \mathrm{~m}$ and increased to $11.2 \mu \mathrm{mol} \mathrm{L}^{-1}$ in the bottom water (Fig. 2c).

Methane $-\mathrm{CH}_{4}$ concentrations in the sediment below $20 \mathrm{~cm}$ depth were stable at $\sim 5 \mathrm{mmol} \mathrm{L}^{-1}$ and decreased toward the sediment-water interface, yet without any discernable shift in $\delta^{13} \mathrm{C}-\mathrm{CH}_{4}$ (Fig. 1b,c). Within the anoxic hypolimnion the $\mathrm{CH}_{4}$ concentration continued to decrease from the near-bottom water $\left(40-160 \mu \mathrm{mol} \mathrm{L}^{-1}\right)$ upwards toward the chemocline (Fig. 1b). Interestingly, the $\mathrm{CH}_{4}$ concentration did not decrease linearly within the deep hypolimnion, and the convex profile well below the chemocline suggests non-conservative behavior-possibly consumption-within the anoxic water column. Moreover, the nonlinear concentration decrease between 220 and $135 \mathrm{~m}$ water depth was accompanied by a ${ }^{13} \mathrm{C}$-isotopic enrichment in the residual $\mathrm{CH}_{4}$ pool, from $-70 \%$ in the deep water to $-40 \%$ at the oxic-anoxic boundary, with a robust closedsystem apparent $\mathrm{C}$-isotope effect ( $\left.\varepsilon_{\text {closed }}\right)$ of $-7 \%$ o to $-9 \%$ o (Fig. 3). Using an open-system model, on the other hand (Eq. 2), the observational data could not be fitted (i.e., no single $\varepsilon$ value could reproduce the observed relationship between $\delta^{13} \mathrm{C}$ and $\left.\left[\mathrm{CH}_{4}\right]\right)$. Below $220 \mathrm{~m}$, only minor $\mathrm{C}$-isotope ratio changes were observed (Fig. 1c). The concentration directly above the top of the anoxic hypolimnion (usually $<20 \mathrm{nmol} \mathrm{L}^{-1}$ ) was only a small fraction of the deep-water concentration just above the sediment during all sampling campaigns.

Methane oxidation rates in the water column-We observed two distinct and (apparently) temporally stable peaks of potential aerobic $\mathrm{CH}_{4}$ turnover rates: one at $145 \mathrm{~m}$ and a second at $175 \mathrm{~m}$ (Fig. 1d). $\mathrm{k}$ values at these depths 


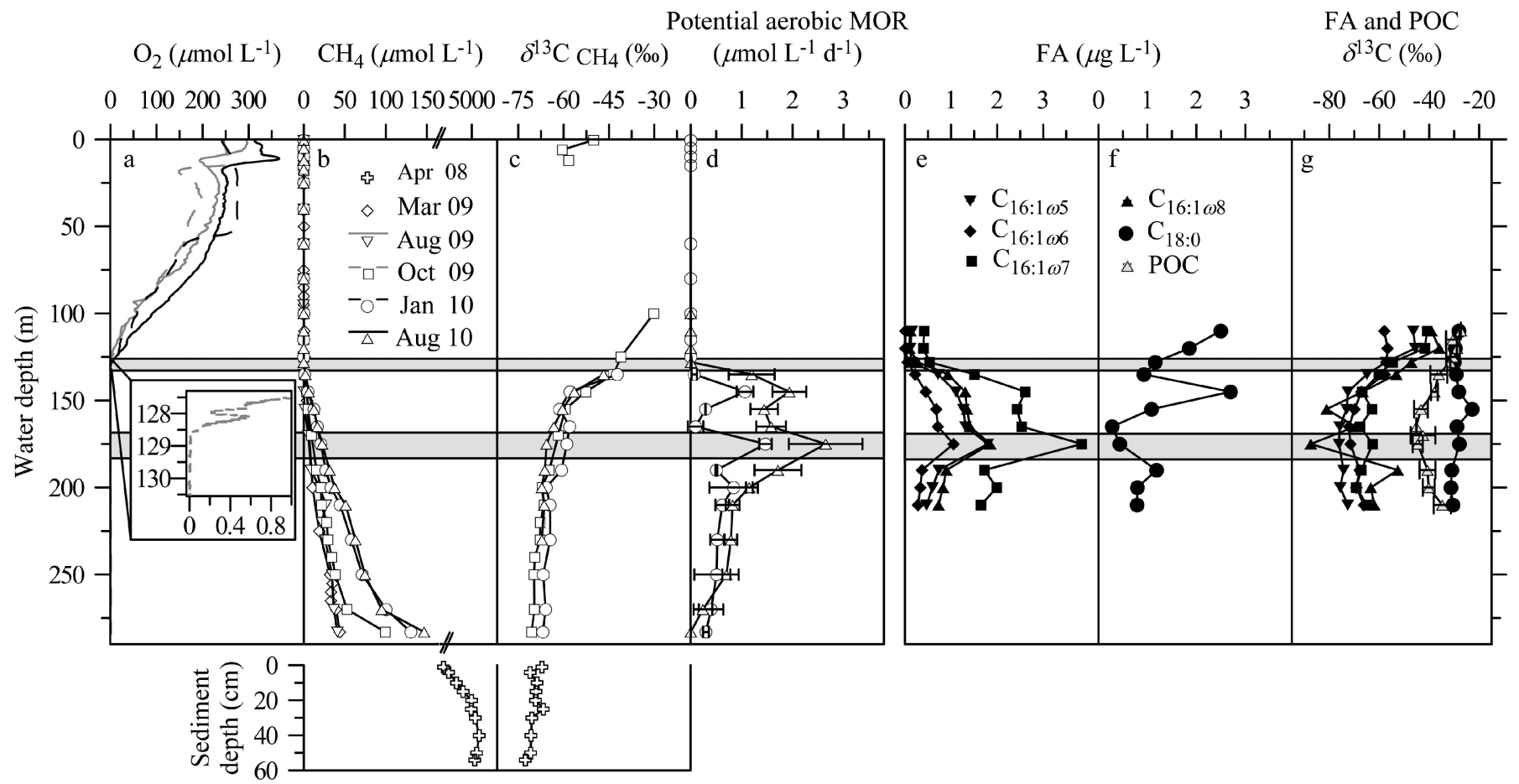

Fig. 1. Hydrochemical profiles of (a) $\mathrm{O}_{2}$ concentration, with a magnification of the sub-micromolar zone in October 2009 (inset), (b) $\mathrm{CH}_{4}$ concentration, (c) $\mathrm{CH}_{4} \delta^{13} \mathrm{C}$ in the water column and sediment, and (d) potential aerobic $\mathrm{CH}_{4}$ oxidation rates. Months are indicated in the legend in (b). Concentration of (e) $\mathrm{C}_{16: 1 \omega 5-8}$ and (f) $\mathrm{C}_{18: 0}$ FAs from August 2010 and (g) $\delta^{13} \mathrm{C}$ of $\mathrm{C}_{16: 1 \omega 5-8}$ and $\mathrm{C}_{18: 0} \mathrm{FAs}$ from August 2010 (black) and average $\delta^{13} \mathrm{C}$ of POC from August 2009, October 2009, January 2010, and August 2010 (gray, 1 standard deviation error bars). The oxic-anoxic interface is indicated by the narrow upper gray bar. The lower gray bar indicates the putative $\mathrm{CH}_{4}$ sink within the anoxic water column, where potential MOR and methanotrophic biomass concentration are highest and where the isotope shift in methanotrophic biomarkers is most pronounced.

were comparably high in August $2010(0.71 \pm 0.02$ and $0.27 \pm 0.05 \mathrm{~d}^{-1}$, respectively) and slightly lower in January $2010\left(0.21 \pm 0.03\right.$ and $0.07 \pm 0.01 \mathrm{~d}^{-1}$, respectively $)$. These $k$ values translate into a MOR of $2.31 \pm 0.34$ and $4.63 \pm$ $0.81 \mu \mathrm{mol} \mathrm{L}-1 \mathrm{~d}^{-1}$ in August and $1.07 \pm 0.16$ and $1.47 \pm$ 0.12 in January. Above, toward the oxic-anoxic interface, potential aerobic MOR decreased to $1 \mu \mathrm{mol} \mathrm{L}^{-1} \mathrm{~d}^{-1}$ and dropped below the detection limit in the oxic water column. Similarly, MOR decreased with depth below $175 \mathrm{~m}$ but remained significant down to near-bottom waters, where they approached the detection limit. In all incubations with measurable $\mathrm{CH}_{4}$ turnover, a residual activity was found after extraction of the carbonate phase. This residual activity was on average $70 \pm 20 \%$ of the turnover into

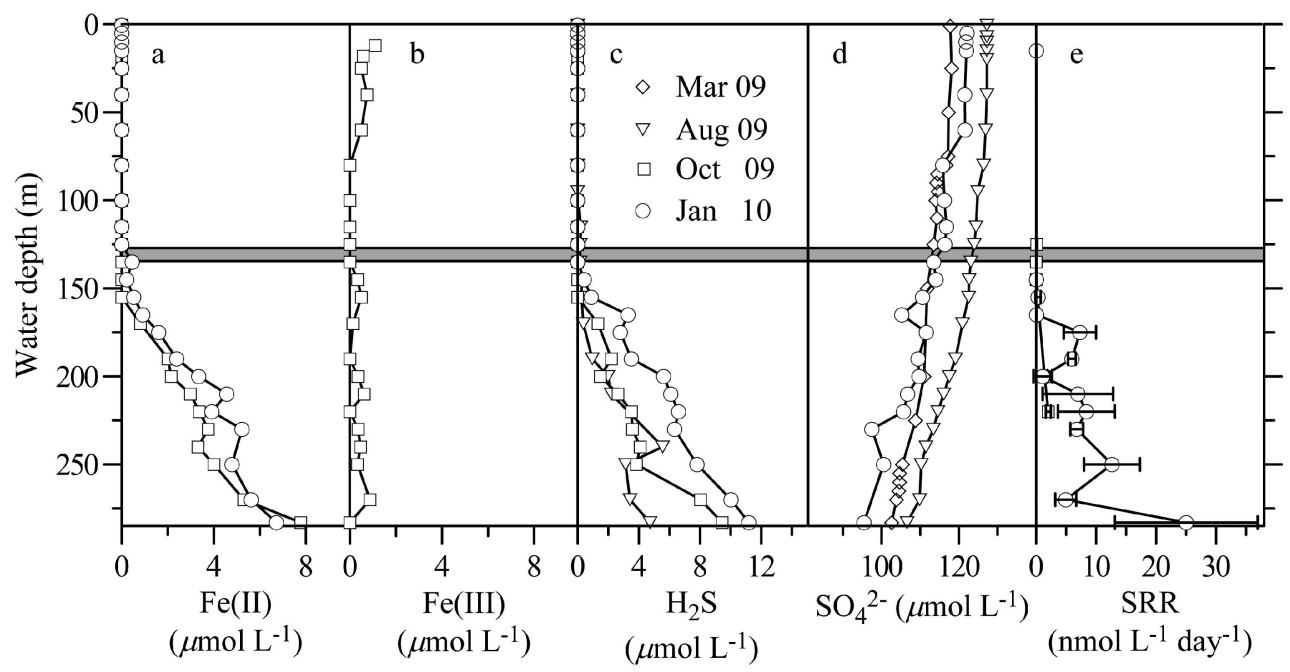

Fig. 2. Water column concentration profiles of (a) Fe(II) and (b) Fe(III), (c) total sulfide, (d) $\mathrm{SO}_{4}^{2-}$, and (e) sulfate reduction rates. The oxic-anoxic interface is indicated by a gray bar. 


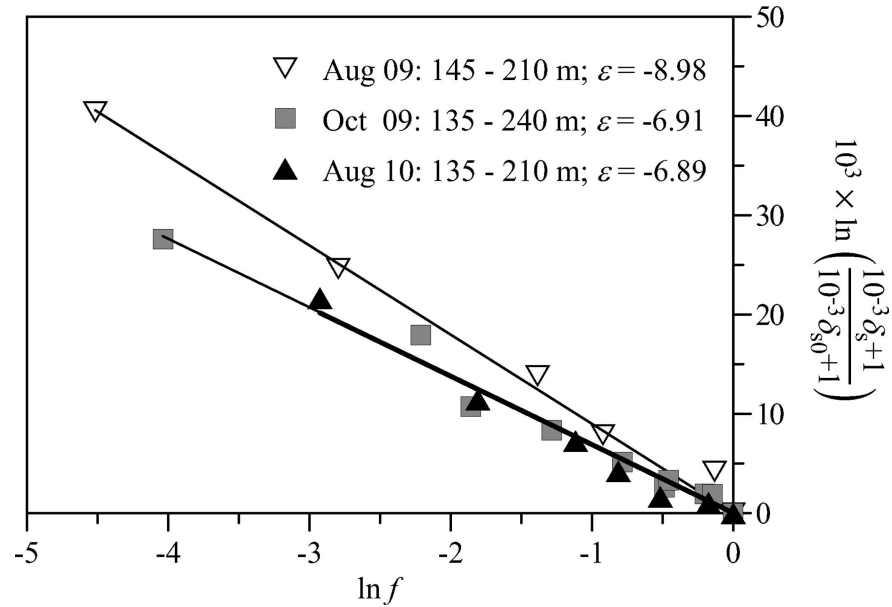

Fig. 3. Rayleigh plot of $\mathrm{CH}_{4}$ data from the anoxic water column of August and October 2009 and August 2010. $f$ is the fraction of methane remaining, with respect to the bottom water methane concentration. Linear regressions are plotted through the three data sets, and the slope is equivalent to the isotope enrichment factor (see Eq. 1). Depth intervals of the linear ranges and their slopes are indicated in the legend.

bicarbonate. Since it constitutes a significant fraction of the ${ }^{14} \mathrm{CH}_{4}$ oxidation, it has been included in the MOR calculation (see Eq. 3). The residual ${ }^{14} \mathrm{C}$ pool was suspended and/or water soluble at low $\mathrm{pH}$ and may have comprised biomass and metabolic intermediates not liberated by acidification. If this residual activity were not included in the MOR calculation, the MOR would be underestimated.

SRRs in the water column-SRR in the hypolimnion was very low, with values of $7.29 \pm 2.69 \mathrm{nmol} \mathrm{L}^{-1} \mathrm{~d}^{-1}$ at $175 \mathrm{~m}$ water depth and up to $37 \mathrm{nmol} \mathrm{L} \mathrm{L}^{-1} \mathrm{~d}^{-1}$ close to the sediment in January 2010 (Fig. 2e). Sulfide accumulated in the deep water, with up to $11.2 \mu \mathrm{mol} \mathrm{L} \mathrm{L}^{-1}$ close to the sediment (Fig. 2c). However, the decline in $\mathrm{SO}_{4}^{2-}$ concentration into the bottom water was significantly greater than the accumulation of sulfide $\left(95 \mu \mathrm{mol} \mathrm{L}^{-1} \mathrm{SO}_{4}^{2-}\right.$ in bottom waters, compared to $120 \mu \mathrm{mol} \mathrm{L} \mathrm{L}^{-1}$ in the oxic water column; Fig. 2d). The discrepancy between apparent sulfate consumption and sulfide production is best explained by the co-precipitation of sulfide with iron, but this aspect was not further investigated.

$P O C$ and lipid biomarkers $-\delta^{13} \mathrm{C}$ values of $\mathrm{POC}$ in the oxic water column were about $-34 \%$ (Fig. 1g). Below the oxycline, POC showed significant ${ }^{13} \mathrm{C}$-isotopic depletion, with $\delta^{13} \mathrm{C}$ values as low as $-47 \%$. Concentration of four mono-unsaturated $\mathrm{C}_{16}$ FAs (with double bonds at positions $\omega 5, \omega 6, \omega 7$, and $\omega 8$ ) increased with depth below the oxicanoxic interface, paralleling the depth distribution of MOR (Fig. 1e), with two temporally stable concentration maxima: one at $145 \mathrm{~m}$ and one at $175 \mathrm{~m}$. The distributions of other bacterial biomarkers such as $i \mathrm{C}_{15}$ and $a i \mathrm{C}_{15}$ displayed similar yet much less-pronounced peaks at the same depths (data not shown). In August 2010 the four $\mathrm{C}_{16: 1}$ lipids accounted for $64 \%$ of total FAs at $175 \mathrm{~m}$. The $\mathrm{C}_{16: 1 \omega 7}$ concentration strongly increased from $0.4 \mu \mathrm{g} \mathrm{L}^{-1}$ just above the oxicanoxic interface to $>1.5 \mu \mathrm{g} \mathrm{L}^{-1}$ in the deep hypolimnion, with a concentration maximum of $3.8 \mu \mathrm{g} \mathrm{L}^{-1}$ at $175 \mathrm{~m}$ water depth. The concentration of other FAs did not increase significantly with depth, except for concentration peaks at the redoxcline at $145 \mathrm{~m}$ (e.g., $\mathrm{C}_{12: 0}, \mathrm{C}_{14: 0}, \mathrm{C}_{15: 0}, \mathrm{C}_{16: 0}$ ). The four mono-unsaturated $\mathrm{C}_{16: 1} \mathrm{FA}$ biomarkers were markedly more depleted in ${ }^{13} \mathrm{C}$ than were other FAs. The most abundant of the four FAs, $\mathrm{C}_{16: 1 \omega 7}$, displayed a $\delta^{13} \mathrm{C}$ as low as $-74.2 \%$ (at $175 \mathrm{~m}$; Fig. 1g). Other lipids displayed 'normal' values of about $-30 \%$ to $-40 \%$. We also investigated other lipid fractions (hydrocarbons and alcohols, the latter typically comprising ether lipids; data not shown). However, none of the analyzed compounds displayed the same conspicuous concentration peaks and characteristic ${ }^{13} \mathrm{C}$-isotopic depletion between 145 and $175 \mathrm{~m}$ water depth. Notably, no archaeal lipids typical for S-AOM (e.g., archaeol, sn2-hydroxyarchaeol, pentamethylicosane, or crocetane [Niemann and Elvert 2008]) or lipids diagnostic of the recently described bacterial AOM by "Candidatus Methylomirabilis oxyfera" (e.g., 10methylhexadecanoic acid [Kool et al. 2012]) were detected during any of the sampling campaigns.

Phylogenetic analyses-Sequences of pmoA could be amplified from all samples collected at the oxic-anoxic interface and in deeper water layers, but not from the oxic water column. After restriction fragment length analysis of MspI-digested inserts of 47 clones, four representatives from $135 \mathrm{~m}$ and five representatives from $170 \mathrm{~m}$ were selected for sequencing. The clones belonged to seven phylotypes, with two phylotypes represented by two clones each. One phylotype was represented by two clones from $170 \mathrm{~m}$ and another by one clone from $135 \mathrm{~m}$ and one from $170 \mathrm{~m}$. The phylogenetic relationship of pmoA sequences from 135 and $170 \mathrm{~m}$ water depth in August 2009 is shown in Fig. 4. They form four clusters within the type I MOB and are closely related to uncultured representatives from oxic environments in Lake Constance (Deutzmann et al. 2011), Lake Washington (Nercessian et al. 2005), and Lake Mizugaki (Tsutsumi et al. 2011). The closest cultured relatives are Methylobacter sp. No sequences of alphaproteobacterial MOB were found.

\section{Discussion}

Anoxia in the water column-Well-constrained information about the geometry of the redox transition zone, and hence the redox state of various levels in the water column, is fundamental for identifying the modes of $\mathrm{CH}_{4}$ oxidation in a waterbody. While the extreme end members of the water column redox spectrum-fully oxygenated and sulfidic - are easily characterized, precise identification of the transition from oxic to hypoxic and, finally, to truly anoxic conditions is challenging. Trace levels of $\mathrm{O}_{2}$ may escape detection because most oxygen sensors have a detection limit of around $1 \mu \mathrm{mol} \mathrm{L}^{-1}$ (Revsbech et al. 2009), and even Winkler titration measurements have uncertainties of $\sim 5 \mu \mathrm{mol} \mathrm{L}{ }^{-1}$ or more (Jalukse et al. 2008). In Lake Lugano, the depth interval between the supposed onset of anoxia and the first appearance of 


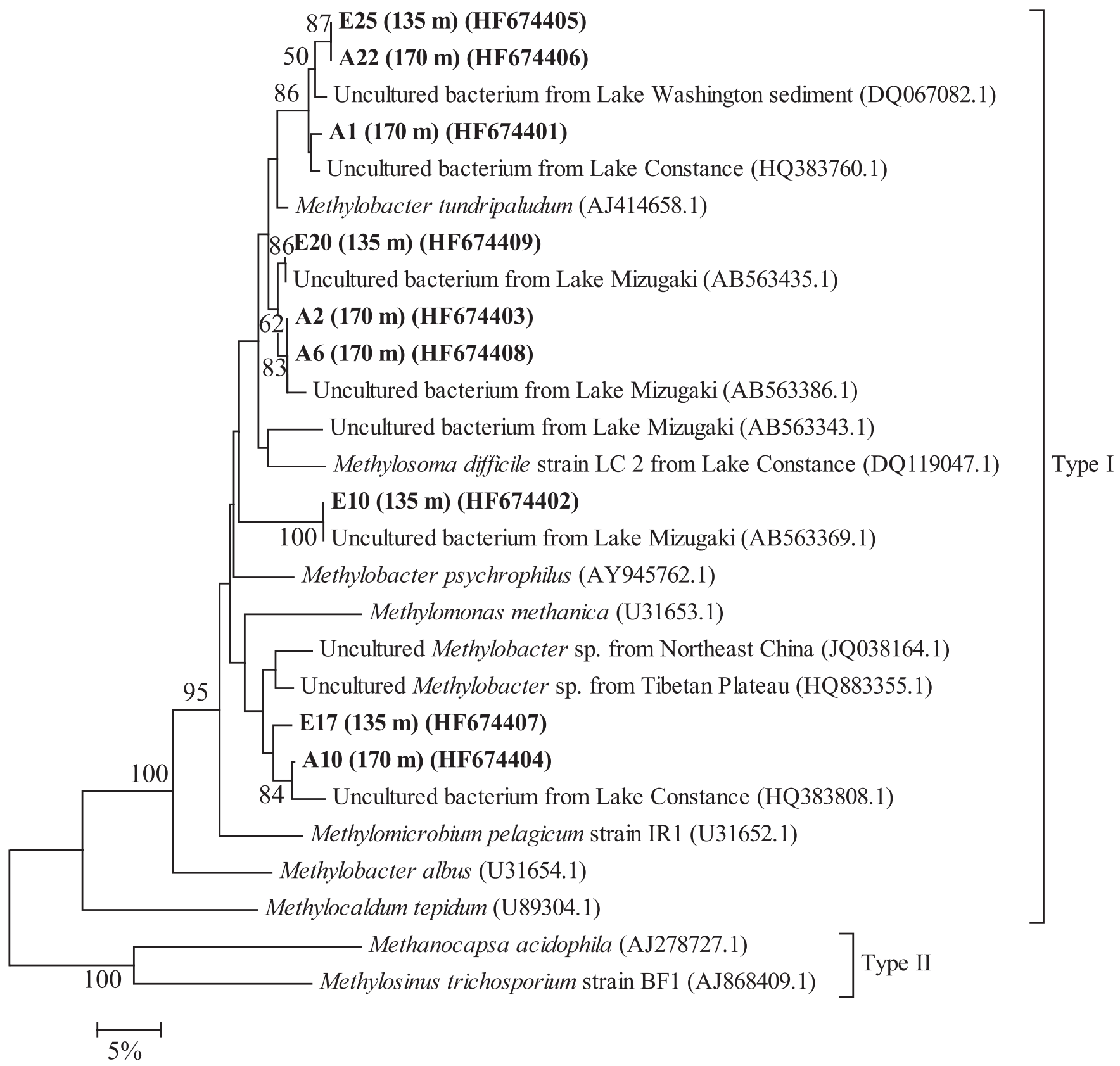

Fig. 4. Neighbor-joining phylogenetic tree of translated amino acid sequences of pmo $A$ gene clones from the oxic-anoxic interface $(135 \mathrm{~m})$ and anoxic deep water $(170 \mathrm{~m})$. Lake Lugano clones are indicated in bold. Twenty-seven amino acid sequences were used for the analysis. Bootstrap values $>50 \%$ (1000 replications) are shown at branch nodes. Closely related sequences from Lakes Mizugaki, Constance, and Washington and two Methylobacter sp. sequences from wetlands are shown for comparison.

sulfide differed by 10 to $35 \mathrm{~m}$. Therefore, we investigated the sub-micromolar $\mathrm{O}_{2}$ zone in high resolution and with nanomolar sensitivity using highly amplified amperometric $\mathrm{O}_{2}$ sensors and $\mathrm{O}_{2}$ optodes (Table 1, Fig. 1a inset; Kirf et al. 2013 ) in order to validate $\mathrm{O}_{2}$ data measured with the CTD device. These measurements showed that the sub-micromolar $\mathrm{O}_{2}$ zone was relatively thin $(1.55 \pm 0.36 \mathrm{~m})$ and the

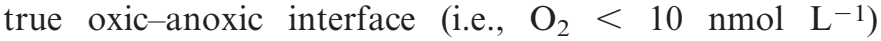
fluctuated between 125.6 and $128.2 \mathrm{~m}$ (i.e., within $5 \mathrm{~m}$ of the $\mathrm{CTD}-\mathrm{O}_{2}$-zero). In fact, throughout our sampling campaigns we never measured $\mathrm{O}_{2}$ at depths below $135 \mathrm{~m}$.

Methane distribution in the hypolimnion and identification of methane sinks-The water column $\mathrm{CH}_{4}$ concentration profiles show highly similar trends of decreasing concentration from the bottom waters toward the oxycline (Fig. 1b), indicating production of $\mathrm{CH}_{4}$ in the sediments and its turbulent diffusive flux through the deep hypolim- 
nion. Based on the concentration and $\delta^{13} \mathrm{C}$ distribution of the sedimentary and water column $\mathrm{CH}_{4}$, four zones are defined for the following discussion.

(1) Sediment pore water-Stable $\mathrm{CH}_{4}$ concentrations in the sediment below $20 \mathrm{~cm}$ and the concentration gradient toward the top of the sediment and into the water column indicate $\mathrm{CH}_{4}$ production below $20 \mathrm{~cm}$ and the diffusive flux of $\mathrm{CH}_{4}$ out of the sediment. The absence of a $\mathrm{C}$-isotope shift in the residual $\mathrm{CH}_{4}$ across the sediment-water interface argues against $\mathrm{CH}_{4}$ oxidation in the sediment pore water, since biological $\mathrm{CH}_{4}$ oxidation results in isotope fractionation, in contrast to turbulent diffusive transport only.

(2) 283-220 $\mathrm{m}$-In the deep hypolimnion, the $\mathrm{CH}_{4}$ concentration profiles display a convex shape that may indicate $\mathrm{CH}_{4}$ consumption in this water layer. However, these nonlinear concentration changes are not paired with a substantial C-isotope shift, which argues against a biogeochemical $\mathrm{CH}_{4}$ sink within this depth interval. Although we cannot completely rule out an anaerobic mode of $\mathrm{CH}_{4}$ oxidation within the deep anoxic hypolimnion, we argue that the shapes of the $\mathrm{CH}_{4}$ concentration and $\delta^{13} \mathrm{C}$ profiles by themselves do not provide conclusive evidence for such a $\mathrm{CH}_{4}$ sink. We further allege that the $\mathrm{CH}_{4}$ concentration in the water column below $\sim 100 \mathrm{~m}$ water depth was not in steady state prior to 2010. Our (Fig. 1b) and unpublished data (University of Applied Sciences of Southern Switzerland [SUPSI] unpubl.) show that $\mathrm{CH}_{4}$ concentrations in the hypolimnion have increased since the holomixis in 2005 and 2006 (Holzner et al. 2009); i.e., from $\sim 40 \mu \mathrm{mol} \mathrm{L}^{-1}$ in spring 2008 to $\sim 160 \mu \mathrm{mol} \mathrm{L}^{-1}$ in 2010. After the mixing events, stratification reestablished and the lower hypolimnion became anoxic again in early 2008 (SUPSI unpubl.). However, steady state with regard to the methane distribution in the water column was not reached at that time. Sediment-derived $\mathrm{CH}_{4}$, liberated into the water column, is transported through the anoxic hypolimnion by turbulent diffusion, and the decreasing water column concentration with distance from the sedimentary source is due to source dilution and mixing with ambient water. The convexshaped $\mathrm{CH}_{4}$ distributions between $220 \mathrm{~m}$ water depth and the sediment can be explained as being the expression of a non-steady state situation, in which the slow vertical transport of $\mathrm{CH}_{4}$ after reestablishment of full meromixis led to a delayed $\mathrm{CH}_{4}$ accumulation in the upper portions of the anoxic hypolimnion.

(3) 220-135 m-The water column between $220 \mathrm{~m}$ and the oxic-anoxic interface at $135 \mathrm{~m}$ is also characterized by a weakly convex $\mathrm{CH}_{4}$ concentration profile (Fig. $1 \mathrm{~b}$ ). In contrast to the lower anoxic hypolimnion, however, we observed a clear ${ }^{13} \mathrm{C}$ enrichment in the residual $\mathrm{CH}_{4}$ pool, suggesting a consumption process in the anoxic water column, tens of meters below the oxic-anoxic interface.
(4) The oxic-anoxic interface $-\mathrm{CH}_{4}$ concentrations of $<20 \mathrm{nmol} \mathrm{L}^{-1}$ immediately above the oxic-anoxic interface indicate that very little $\mathrm{CH}_{4}$ escaped from the deep hypolimnion across the chemocline. This underscores the importance of the oxic part of the redox transition zone as an efficient $\mathrm{CH}_{4}$ filter preventing $\mathrm{CH}_{4}$ emissions to the atmosphere.

MOx at the oxic-anoxic interface-Steep gradients in both $\mathrm{CH}_{4}$ concentration and $\delta^{13} \mathrm{C}$ across the oxic-anoxic interface, which indicate a flux of $1.7-3.0 \mathrm{mmol} \mathrm{m}^{-2} \mathrm{~d}^{-1}$ over the depth range between 190 and $135 \mathrm{~m}$, provide evidence for a strong aerobic $\mathrm{CH}_{4}$ sink in Lake Lugano. The zone of sub-micromolar $\mathrm{O}_{2}$ concentrations is $\sim 1.5 \mathrm{~m}$ thick, and no $\mathrm{CH}_{4}$ oxidation took place at depths with in situ $\mathrm{O}_{2}$ concentration $>1 \mu \mathrm{mol} \mathrm{L}-1$. If we assume an MOx reaction zone with a thickness of $1.5 \mathrm{~m}$, the calculated $\mathrm{CH}_{4}$ flux translates into a $\mathrm{CH}_{4}$ consumption rate of $1.1-$ $2.0 \mu \mathrm{mol} \mathrm{L}^{-1} \mathrm{~d}^{-1}$, in agreement with the rates obtained from ex situ MOR incubations. Assuming a uniform $\mathrm{CH}_{4}$ flux throughout the northern basin of Lake Lugano, with a surface area of $17 \mathrm{~km}^{2}$ at $135 \mathrm{~m}$ depth (SUPSI), and uniform $\mathrm{CH}_{4}$ oxidation at the redoxcline, the total $\mathrm{CH}_{4}$ consumption rate at the oxic-anoxic interface amounts to $10-19 \times 10^{6} \mathrm{~mol} \mathrm{yr}^{-1}$ (i.e., $127-224 \times 10^{3} \mathrm{~kg} \mathrm{C} \mathrm{yr}^{-1}$ ).

High MORs cause a complete consumption of oxygen, creating seemingly anoxic conditions at the depth of highest potential aerobic $\mathrm{CH}_{4}$ oxidation (135-145 m) and possibly driving niche specialization of MOB toward micro-oxic conditions (Tavormina et al. 2013). Assuming a $\mathrm{CH}_{4}: \mathrm{O}_{2}$ stoichiometry of MOx of $1: 1.8$ (Naguib 1976), our $\mathrm{CH}_{4}$ oxidation rates translate into $\mathrm{O}_{2}$ consumption rates of up

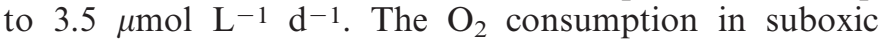

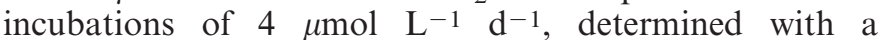
switchable trace oxygen (STOX) sensor (data not shown), supports this value. Based on the $\mathrm{O}_{2}$ concentration profiles, the flux of $\mathrm{O}_{2}$ from the upper hypolimnion toward the oxicanoxic interface ranged between 4.3 and $15 \mathrm{mmol} \mathrm{m}^{-2} \mathrm{~d}^{-1}$, or between 2.9 and $10 \mu \mathrm{mol} \mathrm{L}^{-1} \mathrm{~d}^{-1}$ in a $1.5 \mathrm{~m}$ wide reaction zone. Micro-aerobic MOx is thus responsible for more than one third of the $\mathrm{O}_{2}$ consumption at the redoxcline in the northern basin of Lake Lugano and is therefore an important constraint on the depth of the oxic-anoxic interface.

Further evidence for an MOx community at these depths is indicated by biomarker and phylogenetic data. We found an increase of ${ }^{13} \mathrm{C}$-depleted $\mathrm{FAs}$ at the oxic-anoxic interface, indicating incorporation of $\mathrm{CH}_{4}$-derived carbon into lipid biomass. The ${ }^{13} \mathrm{C}$-isotopic depletion within $\mathrm{C}_{16}$ (particularly $\mathrm{C}_{16: 1 \omega 7}$ ), rather than $\mathrm{C}_{18}$ FAs compared to other lipids (Fig. 1g), indicates a dominance of type I methanotrophs (Bowman et al. 1993; Hanson and Hanson 1996). Moreover, the fractional abundances of the $C_{16: 1 \omega 5-8}$ FAs correspond to those reported for Methylobacter sp. (Hanson and Hanson 1996). A dominance of type I methanotrophs is further confirmed by the sole presence of sequences clustering within the type I MOB related to the Methylobacter sp. in our pmoA clone libraries (Fig. 4). In contrast to the anoxic water column, we could not detect 
the above-mentioned diagnostic biomarkers or pmoA sequences above the oxic-anoxic interface, further supporting that the $\mathrm{CH}_{4}$ sinks are restricted to waters at or below the oxic-anoxic interface.

The absence of MOB above the oxic-anoxic interface agrees well with the fact that ex situ $\mathrm{CH}_{4}$ turnover was only observed in incubations from a depth of $128 \mathrm{~m}$ or below (Fig. 1d). At the depth of maximum potential $\mathrm{CH}_{4}$ turnover $(145 \mathrm{~m})$ the in situ $\mathrm{O}_{2}$ concentration was always < $10 \mathrm{nmol} \mathrm{L}-1$. Very low $\mathrm{O}_{2}$ concentrations have been found to constitute the preferred niche for some aerobic methanotrophs in lakes (Rudd et al. 1976). On the other hand, in incubations of water from the anoxic hypolimnion we did not observe an inhibitory effect of high $\mathrm{O}_{2}$ concentrations ( $100 \mu \mathrm{mol} \mathrm{L}^{-1}$ ) on MOx (data not shown), which indicates that high $\mathrm{O}_{2}$ is not the direct cause of the absence of MOx. Studies on $\mathrm{CH}_{4}$ starvation in $\mathrm{MOB}$ have shown that recovery is significantly faster and more successful when starvation occurred under anoxic conditions rather than under oxic conditions (Roslev and King 1994). Under oxic conditions $\mathrm{MOB}$ were shown to degrade protein during $\mathrm{C}$ starvation, potentially hampering their subsequent ability to oxidize $\mathrm{CH}_{4}$ again, whereas under anoxic conditions only low-molecular-weight compounds were oxidized (Roslev and King 1995). This implies that for $\mathrm{MOB}, \mathrm{O}_{2}$ starvation is preferable to $\mathrm{CH}_{4}$ starvation under oxic conditions. In dynamic systems with spatio-temporal variations of the redoxcline, this may drive MOB toward the anoxic side of the anoxic-oxic continuum, providing protection against the detrimental effects of $\mathrm{CH}_{4}$ starvation under oxic conditions.

Methanotrophy in the anoxic hypolimnion-While the $\mathrm{CH}_{4}$ profiles in the water column between $220 \mathrm{~m}$ and the oxic water leave some ambiguity with regard to the water depth at which $\mathrm{CH}_{4}$ oxidation takes place, and particularly its mode, the lipid biomarker data from the Lake Lugano North Basin provide additional indication for a $\mathrm{CH}_{4}$ oxidation potential below the oxic-anoxic interface. The temporally stable concentration maximum of ${ }^{13} \mathrm{C}$-depleted $\mathrm{C}_{16: 1 \omega 5-8}$ FAs at $\sim 175 \mathrm{~m}$ water depth (Fig. 1e) implies the presence of methanotrophic biomass in anoxic water masses. The dominance of the four $\mathrm{C}_{16: 1} \mathrm{FAs}$ and the absence of ${ }^{13} \mathrm{C}$-depleted archaeal lipids (e.g., isoprenoidal ether lipids or alkanes; Niemann and Elvert 2008) underscores that Bacteria, and not Archaea, drive $\mathrm{CH}_{4}$ oxidation in the northern basin of Lake Lugano. However, lipids characteristic of the recently described "Candidatus Methylomirabilis oxyfera," such as $10-\mathrm{MeC}_{16: 0}$ and 10$\mathrm{MeC}_{16: 1 \omega 9}$ (Kool et al. 2012), were also absent, suggesting no significant contribution of a bacterial pathway of AOM in Lake Lugano. As is the case with the oxic-anoxic interface, only type I MOB related to Methylobacter sp. were found in the pmoA clone libraries (Fig. 4). The absence of a clear distinction between pmoA-phylogenies at 135 and $170 \mathrm{~m}$, and the occurrence of an identical clone at both depths, suggests a high similarity between the bacterial methanotrophic communities.

Accumulation of methanotrophic bacterial biomass in the anoxic vicinity of the chemocline has been described in other systems (Schubert et al. 2006), but not as far as $40 \mathrm{~m}$ below the oxic water column. The methanotrophic biomass can originate from in situ production, but it may also have been 'scavenged' and carried down from the oxic-anoxic interface by sedimenting phyto-detritus. Such a flux of sinking organic matter would be highest after the phytoplankton blooms in March and September. However, the depth of the $\mathrm{CH}_{4}$ oxidation maxima (145 and $175 \mathrm{~m}$; Fig. 1d) appeared to be temporally stable, thus arguing against such a gravity-driven downward transport of MOB from the oxic-anoxic interface. Moreover, we did not observe biomass concentration peaks at other depths, and only the concentration of MOB-derived lipids increased at $175 \mathrm{~m}$, representing further evidence for a selective increase of MOB at this depth, and possibly in situ activity.

MOx potential in anoxic waters - Corresponding to the concentration peak of ${ }^{13} \mathrm{C}$-depleted $\mathrm{C}_{16: 1 \omega 5-8} \mathrm{FAs}$, a local potential MOx rate maximum was found at about $175 \mathrm{~m}$ water depth (Fig. 1d). At this depth, permanent presence of $\mathrm{O}_{2}$ can be excluded as no $\mathrm{O}_{2}$ was detected with the $\mathrm{O}_{2}$ sensors and substantial concentrations of reduced compounds (sulfide, $\mathrm{NH}_{4}^{+}$, and $\mathrm{Fe}(\mathrm{II})$; Fig. 2) act as a natural $\mathrm{O}_{2}$ buffer. Incubation experiments used for MOx rate determination had initial $\mathrm{O}_{2}$ concentrations of around $10 \mu \mathrm{mol} \mathrm{L}-1$. Hence, the obtained potential rates do not reflect methane oxidation under in situ conditions, but they highlight the important potential for aerobic $\mathrm{CH}_{4}$ oxidation in anoxic water masses, well below the oxicanoxic interface. In fact, high MOx potentials were measured not only at $175 \mathrm{~m}$ but throughout the anoxic water column as well (Fig. 1d). Thus, if oxygen were mixed into the anoxic hypolimnion, high aerobic $\mathrm{CH}_{4}$ oxidation rates would be expected, limited only by the availability of $\mathrm{O}_{2}$. We performed incubations with various oxygenation conditions. Most intriguingly, potential methane oxidation rates under oxic conditions ( $>$ $100 \mu \mathrm{mol} \mathrm{L}-1)$ were similar to the rates in micro-oxic $(<$ $5 \mu \mathrm{mol} \mathrm{L}-1)$ incubations. This argues against detrimental effects of high $\mathrm{O}_{2}$ concentrations on MOx (Rudd et al. 1976). Rather, it suggests that the methanotrophic community has adapted to trace levels of $\mathrm{O}_{2}$, reaching maximum turnover at low $\mathrm{O}_{2}$ concentrations (Ren et al. 1997), with half saturation rate constants possibly below micromolar $\mathrm{O}_{2}$ levels (Tiano 2013).

The MOR discussed above were obtained under (micro-) oxic conditions and therefore only reflect in situ $\mathrm{CH}_{4}$ oxidation when $\mathrm{O}_{2}$ is mixed into the deep anoxic hypolimnion. The actual in situ MOR depends on the frequency and amount of $\mathrm{O}_{2}$ supply. With the data in hand it is impossible to estimate the time-integrated or sporadic $\mathrm{O}_{2}$ availability below the redox transition zone. In any case, the potential rates shown in Fig. 1d are almost certainly an overestimate and may be representative for the in situ conditions only when sufficient $\mathrm{O}_{2}$ is mixed into the deep water.

Sources of $\mathrm{O}_{2}$ in the anoxic hypolimnion-We were unable to detect $\mathrm{O}_{2}$ in the water column below $135 \mathrm{~m}$. However, it should be noted that the density stratification in the northern basin of Lake Lugano has been weakened since the overturn events during the winters of 2005-2006 
and 2006-2007 (Holzner et al. 2009). Even though wind energy input and surface water cooling are not sufficient to induce a full overturn of the water column, oxygen-rich cold water masses may episodically, and locally, sink into the anoxic hypolimnion. For example, injections of $\mathrm{O}_{2}$ into hypolimnetic waters have been reported for Lake Maggiore, where sinking of cold fluvial water led to measurable $\mathrm{O}_{2}$ intrusions along the lakes' side walls to depths below $200 \mathrm{~m}$ (Ambrosetti et al. 2010). Moreover, as a result of flood events in tributaries, turbidity currents from the surface waters that reach the bottom waters of the northern basin of Lake Lugano have been observed (Lavelli et al. 2002). However, $\mathrm{O}_{2}$ from episodic inputs is most likely consumed quickly and would likely not be detected by our sampling regime. Yet its consumption during MOx would lead to a decrease in $\mathrm{CH}_{4}$ concentration, coupled to ${ }^{13} \mathrm{C}$ enrichment in the residual $\mathrm{CH}_{4}$ pool, as observed in this study and previously by Liu et al. (1996). More importantly, it could be a plausible explanation for the presence of aerobic $\mathrm{CH}_{4}$ oxidizers in 'stand-by mode' in the upper anoxic hypolimnion.

Relatively low potential MOx rates were also observed below $200 \mathrm{~m}$ (Fig. 1d), where the $\mathrm{CH}_{4}$ concentration decrease is not coupled with a $\mathrm{CH}_{4}$-isotope shift. We putatively attribute the discrepancy between our measurements of potential MOR and the lack of expression in the geochemical environment to the presence of viable MOB in the lower water column (as indicated by low concentrations of ${ }^{13} \mathrm{C}$-depleted FAs; Fig. 1e,f), possibly carried down from the oxycline by sinking particles. These MOB likely recover quickly from $\mathrm{O}_{2}$ starvation once $\mathrm{O}_{2}$ is introduced in laboratory incubations (Roslev and King 1994), resulting in measurable potential MOx rates. However, based on the reduced expression of geochemical signatures diagnostic of in situ MOx $\left(\mathrm{CH}_{4}\right.$ concentration and $\delta^{13} \mathrm{C}$; Fig. $\left.1 \mathrm{~b}, \mathrm{c}\right)$, the lower concentrations of MOx-specific FAs (Fig. 1e,f), and the lower potential aerobic MOR (Fig. 1d) below $200 \mathrm{~m}$ water depth, we argue that any in situ population of aerobic methane oxidizing bacteria in 'stand-by mode,' as postulated for the upper anoxic hypolimnion, is small in the deeper parts of the hypolimnion. This conclusion also seems consistent with our notion that the likelihood of $\mathrm{O}_{2}$ reaching the deeper parts of a strongly stratified waterbody decreases significantly with water depth, particularly in a setting in which MOB higher up in the water column are likely to consume $\mathrm{O}_{2}$ in sinking water masses rapidly.

Scope for true anaerobic methane oxidation and isotopic constraints - As discussed in the previous section, episodic micro-aerobic methane oxidation in otherwise-anoxic waters can explain the occurrence of aerobic methanotrophs and the high potential for MOx in the anoxic hypolimnion. However, since no clear density stratification exists within the anoxic hypolimnion, it is difficult to explain the distinct vertical distribution of methanotrophs in the water column (e.g., the peak at $175 \mathrm{~m}$ water depth). This in turn begs the question of whether a true anaerobic mode of methane oxidation may be part of the hypolimnetic methane filter. The results of incubation experiments under anoxic conditions remained ambiguous. We aimed at testing the potential for AOM in Lake Lugano's northern basin by incubating water samples from $175 \mathrm{~m}$ for time periods of up to $7 \mathrm{~d}$. In some of the anoxic incubations, no $\mathrm{CH}_{4}$ oxidation took place. In other incubations, even when an $\mathrm{O}_{2}$ scavenger $\left(15 \mu \mathrm{mol} \mathrm{L}-1 \mathrm{H}_{2} \mathrm{~S}\right)$ was used, we found persistent $\mathrm{CH}_{4}$ turnover after several days. As is the case for any elastomer, there is no material that is totally diffusion tight. However, we monitored $\mathrm{O}_{2}$ leakage through the bromo-butyl stopper in parallel incubations with MilliQ water. Over $30 \mathrm{~d}$, we measured a sulfide concentration decrease of $0.15 \mu \mathrm{mol} \mathrm{L} \mathrm{L}^{-1} \mathrm{~d}^{-1}$, which translates to an influx of $\mathrm{O}_{2}$ of $\sim 0.3 \mu \mathrm{mol} \mathrm{L} \mathrm{L}^{-1} \mathrm{~d}^{-1}$, under the conservative assumption that sulfide is completely oxidized to $\mathrm{SO}_{4}^{2-}$. The $\mathrm{O}_{2}$ leakage flux is thus $>$ fivefold lower than required if the late-stage $\mathrm{CH}_{4}$ turnover were due to MOx. Still, we cannot offer an explanation with respect to a potential, alternative electron acceptor for $\mathrm{CH}_{4}$ oxidation. Sulfate reduction could not account for the observed $\mathrm{CH}_{4}$ oxidation, given that the ex situ SRR was 100-fold lower than $\mathrm{CH}_{4}$ oxidation (Figs. 1d, 2e). Similarly, concentrations of other potential electron acceptors such as $\mathrm{NO}_{3}^{-}$or $\mathrm{NO}_{2}^{-}$(Wenk et al. 2013) or $\mathrm{Fe}$ (III) (Fig. 2b) were too low $\left(<1 \mu \mathrm{mol} \mathrm{L}^{-1}\right)$ to account for the observed $\mathrm{CH}_{4}$ turnover. Further investigations are required to ascertain potential anaerobic modes of $\mathrm{CH}_{4}$ oxidation in Lake Lugano's anoxic hypolimnion.

Biochemical processes impose an isotopic fractionation on the substrate that can be intrinsic to the enzymatic pathway. A characteristic ${ }^{13} \mathrm{C}$-to- $\mathrm{CH}_{4}$ concentration relationship (constrained by a characteristic $\varepsilon$ ) may help to diagnose the pathway of methane oxidation better. MOx is typically associated with $\varepsilon$ values between $-15 \%$ and $-30 \%$, with pMMO-based $\mathrm{CH}_{4}$ oxidation leading to larger fractionation (Jahnke et al. 1999). In contrast to an opensystem model, a closed-system Rayleigh model described the Lake Lugano data quite well, yet the resulting apparent ${ }^{13} \mathrm{C}$ isotope effect for methane oxidation in the hypolimnion (Eq. 1) ranged between $-6.9 \%$ and $-9.0 \%$ (Fig. 3). This is significantly lower than the organism-level $\varepsilon$ values expected for MOx. An anaerobic $\mathrm{CH}_{4}$ oxidation process with lower $\mathrm{C}$-isotope fractionation could be invoked to explain the low $\varepsilon$ values. However, estimates for $\varepsilon$ values of known modes of AOM are scarce and rather indistinct (with values between $-12 \%$ and $-39 \%$; Holler et al. 2009), so that they do not serve as a robust point of comparison with which to diagnose AOM in Lake Lugano unambiguously. We also recognize that the closed-system approach may not be fully appropriate for this system. The isotope effects assessed on the ecosystem level may be lower by several per mil compared to the biological isotope effect at the cellular level, especially in the case of complete substrate consumption (see Thunell et al. [2004], Lehmann et al. [2007] and Wenk et al. [2014] for a discussion on $\varepsilon$ suppression). In contrast to $\mathrm{CH}_{4}$ oxidation at the oxycline, $\mathrm{CH}_{4}$ occurs in micromolar concentrations throughout large parts of the water column where potential methane turnover is observed (between $220 \mathrm{~m}$ and $145 \mathrm{~m}$ ), arguing against a substrate limitation-driven suppression of $\varepsilon$. However, in case of a temporally discontinuous process, in which periods of MOx with large fractionation alternate with periods without consumption, mixing along the concentration gradient dampens the expression of $\varepsilon$ in the ambient water, possibly leading to the observed lowered $\varepsilon$ values. In conclusion, the apparent or 
ecosystem-scale C-isotope effects for Lake Lugano determined here most likely do not represent $\mathrm{C}$-isotope fractionation at the enzyme level and are hence of limited use for pinpointing the dominant mode of methane oxidation.

Our study provides the first in situ geochemical evidence of aerobic $\mathrm{CH}_{4}$ oxidation at nanomolar $\mathrm{O}_{2}$ concentrations, below the detection limit of common $\mathrm{O}_{2}$ sensors, in a lacustrine environment. Micro-aerobic $\mathrm{CH}_{4}$ oxidation is responsible for $\mathrm{CH}_{4}$ consumption at the oxic-anoxic interface on the order of 1.7-3.0 mmol $\mathrm{CH}_{4} \mathrm{~m}^{-2} \mathrm{~d}^{-1}$, amounting to a total annual turnover at the redoxcline (approximately $17 \mathrm{~km}^{2}$ ) of $127-224 \times 10^{3} \mathrm{~kg} \mathrm{C}$. Our data also suggest $\mathrm{CH}_{4}$ consumption within the anoxic hypolimnion. The concentration and $\delta^{13} \mathrm{C}$ depth distributions of $\mathrm{CH}_{4}$ and lipid biomarkers in the anoxic hypolimnion of Lake Lugano's northern basin could (possibly erroneously) be interpreted as AOM. However, the evidence for AOM in Lake Lugano remains ambiguous. We provide multiple lines of evidence for micro-aerobic methane oxidation (MOx) even $40 \mathrm{~m}$ below the chemocline. MOB appear to survive prolonged periods of $\mathrm{O}_{2}$ starvation in a state of anaerobic dormancy, but rapidly resume micro-aerobic MOx upon episodic introduction of $\mathrm{O}_{2}$. This adaptation may represent an efficient strategy with which to avoid the detrimental effects of $\mathrm{CH}_{4}$ starvation under oxic conditions and to escape grazing pressure in more oxygenated water. The long-term presence of potentially active MOB deep within the anoxic water column implies that $\mathrm{O}_{2}$-rich water is downwelled episodically, yet the exact mechanisms that induce $\mathrm{O}_{2}$ injection and lead to the apparent blurring of anoxic and suboxic ecological regimes require further investigation. Micro-aerobic $\mathrm{CH}_{4}$ oxidation both well below and at the oxic-anoxic interface make the hypolimnion of the Lake Lugano North Basin an efficient $\mathrm{CH}_{4}$ filter, preventing export of $\mathrm{CH}_{4}$ to the upper hypolimnion and epilimnion and, ultimately, preventing emission to the atmosphere.

\section{Acknowledgments}

We thank Marco Simona and Stefano Beatrizotti for their excellent support with work on Lake Lugano. We thank Mark Rollog and Marianne Caroni for support in our laboratories at the University of Basel and Gijs Nobbe and Gabriele Schüssler for assistance in the laboratories at the Swiss Federal Institute of Aquatic Science and Technology (EAWAG) and the Max Planck Institute for Marine Microbiology, respectively. We are grateful to Bo Thamdrup for his help in determining oxygen consumption rates and the extent of contamination in the incubation water. We also thank Antje Boetius for generously providing laboratory facilities for methane oxidation rate measurements. We would like to express our gratitude to two anonymous reviewers, whose insightful comments have helped improve the quality of this manuscript. This study was funded through Swiss National Science Foundation grant 121861 (Biogeochemical fluxes in south-alpine lakes: Linking nitrogen and methane dynamics in lacustrine redox-transition zones using a combined stable isotope and molecular approach).

\section{References}

Aeschbach-Hertig, W., C. P. Holzner, M. Hofer, M. Simona, A. BARbieri, AND R. Kipfer. 2007. A time series of environmental tracer data from deep, meromictic Lake Lugano, Switzerland. Limnol. Oceanogr. 52: 257-273, doi:10.4319/1o.2007.52.1.0257
Ambrosetti, W., L. Barbanti, and E. A. Carrara. 2010. Mechanisms of hypolimnion erosion in a deep lake (Lago Maggiore, N. Italy). J. Limnol. 69: 3-14, doi:10.4081/jlimnol.2010.3

Barbieri, A., and R. Mosello. 1992. Chemistry and trophic evolution of Lake Lugano in relation to nutrient budget. Aquat. Sci. 54: 219-237, doi:10.1007/BF00878138

—, AND M. Simona. 2001. Trophic evolution of Lake Lugano related to external load reduction: Changes in phosphorus and nitrogen as well as oxygen balance and biological parameters. Lakes Reserv Res. Manag. 6: 37-47, doi:10.1046/j. 1440-1770.2001.00120.x

Bastviken, D., J. J. Cole, M. L. Pace, and L. Tranvik. 2004. Methane emissions from lakes: Dependence of lake characteristics, two regional assessments, and a global estimate. Glob. Biogeochem. Cycles 18: 1-12, doi:10.1029/2004GB002238

, J. Ejlertsson, And L. Tranvik. 2002. Measurement of methane oxidation in lakes: A comparison of methods. Environ. Sci. Technol. 36: 3354-3361, doi:10.1021/es010311p

Beal, E. J., C. H. House, and V. J. Orphan. 2009. Manganese and iron-dependent marine methane oxidation. Science 325: 184-187, doi:10.1126/science.1169984

Bowman, J. P., L. I. Sly, P. D. Nichols, and A. C. Hayward. 1993. Revised taxonomy of the methanotrophs: Description of Methylobacter gen. nov., emendation of Methylococcus, validation of Methylosinus and Methylocystis species, and a proposal that the family Methylococcaceae includes only the group I methanotrophs. Int. J. Syst. Bacteriol. 43: 735-755, doi:10.1099/00207713-43-4-735

Bussmann, I., M. Rahalkar, And B. Schink. 2006. Cultivation of methanotrophic bacteria in opposing gradients of methane and oxygen. FEMS Microbiol. Ecol. 56: 331-344, doi:10. 1111/j.1574-6941.2006.00076.x

Chen, Y.-H., And R. G. Prinn. 2006. Estimation of atmospheric methane emissions between 1996 and 2001 using a threedimensional global chemical transport model. J. Geophys. Res. 111: D10307, doi:10.1029/2005JD006058

Costello, A. M., And M. E. Lidstrom. 1999. Molecular characterization of functional and phylogenetic genes from natural populations of methanotrophs in lake sediments. Appl. Environ. Microbiol. 65: 5066-5074.

Crowe, S. A., AND OTHERs. 2010. The methane cycle in ferruginous Lake Matano. Geobiology 9: 61-78, doi:10.1111/j.1472-4669. 2010.00257.x

Deutzmann, J. S., S. Wörner, And B. Schink. 2011. Activity and diversity of methanotrophic bacteria at methane seeps in eastern Lake Constance sediments. Appl. Environ. Microbiol. 77: 2573-2581, doi:10.1128/AEM.02776-10

Diaz, R. J., And R. Rosenberg. 2008. Spreading dead zones and consequences for marine ecosystems. Science 321: 926-929, doi:10.1126/science. 1156401

Elvert, M., A. Boetius, K. Knittel, and B. B. Jørgensen. 2003. Characterization of specific membrane fatty acids as chemotaxonomic markers for sulfate-reducing bacteria involved in anaerobic oxidation of methane. Geomicrobiol. J. 20: 403-419, doi:10.1080/01490450303894

Ettwig, K. F., T. van Alen, K. T. van de Pas-Schoonen, M. S. M. Jetten, And M. Strous. 2009. Enrichment and molecular detection of denitrifying methanotrophic bacteria of the NC10 phylum. Appl. Environ. Microbiol. 75: 3656-3662, doi:10.1128/AEM.00067-09

- AND OTHERS. 2010. Nitrite-driven anaerobic methane oxidation by oxygenic bacteria. Nature 464: 543-548, doi:10.1038/nature08883

Gargett, A. E. 1984. Vertical eddy diffusivity in the ocean interior. J. Mar. Res. 42: 359-393, doi:10.1357/002224084788502756 
Hanson, R. S., and T. E. Hanson. 1996. Methanotrophic bacteria. Microbiol. Rev. 60: 439-471.

HiLl, R. 1930. Method for the estimation of iron in biological material. P. R. Soc. London B107: 205-214, doi:10.1098/rspb.1930.0063

Holler, T., G. Wegener, K. Knittel, A. Boetius, B. Brunner, M. M. M. KuYPers, AND F. WidDEL. 2009. Substantial ${ }^{13} \mathrm{C} / 12 \mathrm{C}$ and $\mathrm{D} / \mathrm{H}$ fractionation during anaerobic oxidation of methane by marine consortia enriched in vitro. Environ. Microbiol. Rep. 1: 370-376, doi:10.1111/j.1758-2229.2009.00074.x

Holmes, A. J., A. Costello, M. E. Lidstrom, and J. C. Murrell. 1995. Evidence that particulate methane monooxygenase and ammonia monooxygenase may be evolutionarily related. FEMS Microbiol. Lett. 132: 203-208, doi:10.1111/j.1574-6968. 1995.tb07834.x

Holzner, C. P., W. Aeschbach-Hertig, M. Simona, M. Veronesi, D. M. Imboden, AND R. Kipfer. 2009. Exceptional mixing events in meromictic Lake Lugano (Switzerland/Italy), studied using environmental tracers. Limnol. Oceanogr. 54: 1113-1124, doi:10.4319/1o.2009.54.4.1113

Intergovernmental Panel on Climate Change (IPCC). 2007. Changes in atmospheric constituents and in radiative forcing, p. 129-234. In S. Solomon, D. Qin, M. Manning, Z. Chen, M. Marquis, K. B. Averyt, M. Tignor, and H. L. Miller [eds], Climate change 2007: The physical science basis. Contribution of Working Group I to the fourth assessment report of the Intergovernmental Panel on Climate Change. Cambridge Univ. Press.

Jahnke, L. L., R. E. Summons, J. M. Hope, and D. J. Des Marais. 1999. Carbon isotopic fractionation in lipids from methanotrophic bacteria II: The effects of physiology and environmental parameters on the biosynthesis and isotopic signatures of biomarkers. Geochim. Cosmochim. Acta 63: 79-93, doi:10.1016/S0016-7037(98)00270-1

Jalukse, L., I. Helm, O. SAKs, AND I. Leito. 2008. On the accuracy of micro Winkler titration procedures: A case study. Accredit. Qual. Assur. 13: 575-579, doi:10.1007/s00769-008-0419-1

Kallmeyer, J., T. G. Ferdelman, A. Weber, H. Fossing, and B. B. JøRGensen. 2004. A cold chromium distillation procedure for radiolabeled sulfide applied to sulfate reduction measurements. Limnol. Oceanogr.: Methods 2: 171-180, doi:10.4319/lom.2004.2.171

Kirf, M. K., C. Dinkel, C. J. Schubert, and B. Wehrli. 2013. Submicromolar oxygen profiles at the oxic-anoxic boundary of temperate lakes. Aquat. Geochem, doi:10.1007/s10498-0139206-7

Knittel, K., And A. Boetius. 2009. Anaerobic oxidation of methane: Progress with an unknown process. Annu. Rev. Microbiol. 63: 311-334, doi:10.1146/annurev.micro.61.080706. 093130

Kool, D. M., B. Zhu, W. I. C. Rijpstra, M. S. M. Jetten, K. F. EtTwig, And J. S. Sinninghe Damsté. 2012. Rare branched fatty acids characterize the lipid composition of the intra-aerobic methane oxidizer "Candidatus Methylomirabilis oxyfera." Appl. Environ. Microbiol. 78: 8650-8656, doi:10.1128/AEM. 02099-12

Lavelli, A., G. De Cesare, And J.-L. Boillat. 2002. Numerical 3D modelling of the vertical mass exchange induced by turbidity currents in Lake Lugano (Switzerland). In Proceedings 5th International Conference on Hydro-Science and -Engineering (ICHE-2002) (Reference: LCH-CONF-2002-012 Note: [355]).

Lehmann, M. F., D. M. Sigman, D. C. McCorkle, J. Granger, S. Hoffmann, G. Cane, and B. G. Brunelle. 2007. The distribution of nitrate ${ }^{15} \mathrm{~N} / 14 \mathrm{~N}$ in marine sediments and the impact of benthic nitrogen loss on the isotopic composition of oceanic nitrate. Geochim. Cosmochim. Acta 71: 5384-5404, doi:10.1016/j.gca.2007.07.025
Liu, R., A. Hofmann, F. O. Gülaçar, P.-Y. Favarger, and J. DominiK. 1996. Methane concentration profiles in a lake with a permanently anoxic hypolimnion (Lake Lugano, Switzerland-Italy). Chem. Geol. 133: 201-209, doi:10.1016/S00092541(96)00090-3

Mariotti, A., J. C. Germon, P. Hubert, P. Kaiser, R. Letolle, A. TARdieux, And P. TARdieux. 1981. Experimental determination of nitrogen kinetic isotope fractionation: Some principles; Illustrations for the denitrification and nitrification processes. Plant Soil 62: 413-430, doi:10.1007/BF02374138

Mau, S., J. Blees, E. Helmke, H. Niemann, and E. Damm. 2013. Vertical distribution of methane oxidation and methanotrophic response to elevated methane concentrations in stratified waters of the Arctic fjord Storfjorden (Svalbard, Norway). Biogeosciences 10: 6267-6268, doi:10.5194/bg-106267-2013

Moss, C. W., And M. A. Lambert-Fair. 1989. Location of double bonds in monounsaturated fatty acids of Campylobacter cryaerophila with dimethyl disulfide derivatives and combined gas chromatography-mass spectrometry. J. Clin. Microbiol. 27: $1467-1470$.

Naguib, M. 1976. Stoichiometry of methane oxidation in the methane-oxidizing strain M 102 under the influence of various $\mathrm{CH}_{4} / \mathrm{O}_{2}$ mixtures. Z. Allg. Mikrobiol. 16: 437-444, doi:10.1002/jobm.3630160604

Nercessian, O., E. Noyes, M. G. Kalyuzhnaya, M. E. Lidstrom, And L. Chistoserdova. 2005. Bacterial populations active in metabolism of $\mathrm{C}_{1}$ compounds in the sediment of Lake Washington, a freshwater lake. Appl. Environ. Microbiol. 71: 6885-6899, doi:10.1128/AEM.71.11.6885-6899.2005

Nichols, P. D., J. B. Guckert, and D. C. White. 1986. Determination of monounsaturated fatty acid double-bond position and geometry for microbial monocultures and complex consortia by capillary GC-MS of their dimethyl disulphide adducts. J. Microbiol. Methods 5: 49-55, doi:10. 1016/0167-7012(86)90023-0

Niemann, H., And M. Elvert. 2008. Diagnostic lipid biomarker and stable carbon isotope signatures of microbial communities mediating the anaerobic oxidation of methane with sulphate. Org. Geochem. 39: 1668-1677, doi:10.1016/j.orggeochem.2007.11.003

, AND OTHERs. 2005. Methane emission and consumption at a North Sea gas seep (Tommeliten area). Biogeosciences 2: 335-351, doi:10.5194/bg-2-335-2005

Panganiban, A., T. Patt, W. Hart, and R. S. Hanson. 1979. Oxidation of methane in the absence of oxygen in lake water samples. Appl. Environ. Microbiol. 37: 303-309.

Rees, T. D., A. B. Gyllenspetz, and A. C. Docherty. 1971. The determination of trace amounts of sulphide in condensed steam with $N N$-diethyl- $p$-phenylenediamine. Analyst 96: 201-208, doi:10.1039/an9719600201

Ren, T., J. A. Amaral, and R. Knowles. 1997. The response of methane consumption by pure cultures of methanotrophic bacteria to oxygen. Can. J. Microbiol. 43: 925-928, doi:10. 1139/m97-133

Revisbech, N. P., L. H. Larsen, J. Gundersen, T. Dalsgaard, O. UlloA, And B. Thamdrup. 2009. Determination of ultra-low oxygen concentrations in oxygen minimum zones by the STOX sensor. Limnol. Oceanogr.: Methods 7: 371-381, doi:10.4319/lom.2009.7.371

Roslev, P., And G. M. King. 1994. Survival and recovery of methanotrophic bacteria starved under oxic and anoxic conditions. Appl. Environ. Microbiol. 60: 2602-2608.

, AND - 1995. Aerobic and anaerobic starvation metabolism in methanotrophic bacteria. Appl. Environ. Microbiol. 61: 1563-1570. 
Rudd, J. W. M., A. Furutani, R. J. Flett, and R. D. Hamilton. 1976. Factors controlling methane oxidation in shield lakes: The role of nitrogen fixation and oxygen concentration. Limnol. Oceanogr. 21: 357-364, doi:10.4319/lo.1976.21.3.0357

Schubert, C. J., AND OTHERs. 2006. Aerobic and anaerobic methanotrophs in the Black Sea water column. Environ. Microbiol. 8: 1844-1856, doi:10.1111/j.1462-2920.2006.01079.x , AND . 2010. Oxidation and emission of methane in a monomictic lake (Rotsee, Switzerland). Aquat. Sci. 72: 455-466, doi:10.1007/s00027-010-0148-5

Shrestha, M., W.-R. Abraham, P. M. Shrestha, M. Noll, and R. Conrad. 2008. Activity and composition of methanotrophic bacterial communities in planted rice soil studied by flux measurements, analyses of pmo $A$ gene and stable isotope probing of phospholipid fatty acids. Environ. Microbiol. 10: 400-412, doi:10.1111/j.1462-2920.2007.01462.x

Sigman, D. M., R. Robinson, A. N. Knapp, A. van Geen, D. C. McCorkle, J. A. Brandes, And R. C. Thunell. 2003. Distinguishing between water column and sedimentary denitrification in the Santa Barbara Basin using the stable isotopes of nitrate. Geochem. Geophys. Geosyst. 4, doi:10.1029/2002GC000384

Sivan, O., M. Adler, A. Pearson, F. Gelman, I. Bar-Or, S. G. John, AND W. ECKert. 2011. Geochemical evidence for ironmediated anaerobic oxidation of methane. Limnol. Oceanogr. 56: 1536-1544, doi:10.4319/1o.2011.56.4.1536

Tamura, K., D. Peterson, N. Peterson, G. Stecher, M. Nei, and S. KumAR. 2011. MEGA5: Molecular evolutionary genetics analysis using maximum likelihood, evolutionary distance, and maximum parsimony methods. Mol. Biol. Evol. 28: 2731-2739, doi:10.1093/molbev/msr121

Tavormina, P. L., W. Ussler, J. A. Steele, S. A. Connon, M. G. Klotz, and V. J. Orphan. 2013. Abundance and distribution of diverse membrane-bound monooxygenase ( $\mathrm{Cu}-\mathrm{MMO})$ genes within the Costa Rica oxygen minimum zone. Environ. Microbiol. Rep. 5: 414 423, doi:10.1111/1758-2229.12025

Thunell, R. C., D. M. Sigman, F. Muller-Karger, Y. Astor, And R. VARela. 2004. Nitrogen isotope dynamics of the Cariaco Basin, Venezuela. Glob. Biogeochem. Cycles 18: GB3001.

TIANO, L. 2013. Microbial respiration and gene expression as a function of very low oxygen concentration. Ph.D. thesis. Aarhus Univ.

Treude, T., A. Boetius, K. Knittel, K. Wallmann, and B. B. JøRGENSEN. 2003. Anaerobic oxidation of methane above gas hydrates at Hydrate Ridge, NE Pacific Ocean. Mar. Ecol. Prog. Ser. 264: 1-14, doi:10.3354/meps264001
Trotsenko, Y. A., And J. C. Murrell. 2008. Metabolic aspects of aerobic obligate methanotrophy. Adv. Appl. Microbiol. 63: 183-229, doi:10.1016/S0065-2164(07)00005-6

Tsutsumi, M., T. Iwata, H. Kojima, And M. Funui. 2011. Spatiotemporal variations in an assemblage of closely related planktonic aerobic methanotrophs. Freshw. Biol. 56: 342 351, doi:10.1111/j.1365-2427.2010.02502.x

Wenk, C. B., AND OTHERs. 2013. Anaerobic ammonium oxidation (anammox) bacteria and sulfide-dependent denitrifiers coexist in the water column of a meromictic south-alpine lake. Limnol. Oceanogr. 58: 1-12, doi:10.4319/1o.2013.58.1.0001 -, J. Zopfi, J. Blees, M. Veronesi, H. Niemann, and M. F. Lehmann. 2014. Community $\mathrm{N}$ and $\mathrm{O}$ isotope fractionation by sulfide-dependent denitrification and anammox in a stratified lacustrine water column. Geochim. Cosmochim. Acta 125: 551-563, doi:10.1016/j.gca.2013.10.034

Whiticar, M. J., AND E. FABer. 1986. Methane oxidation in sediment and water column environments - isotope evidence. Org. Geochem. 10: 759-768, doi:10.1016/S0146-6380(86) 80013-4

Wüest, A., W. Aeschbach-Hertig, H. Baur, M. Hofer, R. Kipfer, AND M. SChurter. 1992. Density structure and tritium-helium age of deep hypolimnetic water in the northern basin of Lake Lugano. Aquat. Sci. 54: 205-218, doi:10.1007/BF00878137

Zaikova, E., D. A. Walsh, C. P. Stilwell, W. W. Mohn, P. D. Tortell, And S. J. Hallam. 2010. Microbial community dynamics in a seasonally anoxic fjord: Saanich Inlet, British Columbia. Environ. Microbiol. 12: 172-191, doi:10.1111/ j.1462-2920.2009.02058.x

Zopfi, J., T. G. Ferdelman, B. B. Jorgensen, A. Teske, and B. ThAMDRuP. 2001. Influence of water column dynamics on sulfide oxidation and other major biogeochemical processes in the chemocline of Mariager Fjord (Denmark). Mar. Chem. 74: 29-51, doi:10.1016/S0304-4203(00)00091-8

Associate editor: Mary I. Scranton

Received: 20 February 2013

Accepted: 27 September 2013 Amended: 22 October 2013 